Article

\title{
Impact of COVID19 on Operational Activities of Manufacturing Organizations-A Case Study and Industry 4.0-Based Survive-Stabilise-Sustainability (3S) Framework
}

\author{
Mutahhar A. Dar, Bartlomiej Gladysz *(D) and Aleksander Buczacki (D) \\ Faculty of Production Engineering, Warsaw University of Technology, 02-524 Warsaw, Poland; \\ mutahhar_ahmad.dar.stud@pw.edu.pl (M.A.D.); aleksander.buczacki@pw.edu.pl (A.B.) \\ * Correspondence: bartlomiej.gladysz@pw.edu.pl
}

Citation: Dar, M.A.; Gladysz, B.; Buczacki, A. Impact of COVID19 on Operational Activities of

Manufacturing Organizations-A Case Study and Industry 4.0-Based Survive-Stabilise-Sustainability (3S) Framework. Energies 2021, 14, 1900. https://doi.org/10.3390/en14071900

Academic Editor: Patrycja Hąbek

Received: 6 March 2021

Accepted: 26 March 2021

Published: 30 March 2021

Publisher's Note: MDPI stays neutral with regard to jurisdictional claims in published maps and institutional affiliations.

Copyright: (c) 2021 by the authors. Licensee MDPI, Basel, Switzerland. This article is an open access article distributed under the terms and conditions of the Creative Commons Attribution (CC BY) license (https:// creativecommons.org/licenses/by/ $4.0 /)$.

\begin{abstract}
The SARS-CoV-2 pandemic is spreading rapidly and threatening lives all over the globe. Due to the pandemic, economies all over the world are in deep distress due to disruption in work and operations across all sectors. The present case study was performed for a private Indian manufacturing company that has been affected to a great extent due to this pandemic, as India has the second highest number of SARS-CoV-2 cases after the USA. The deeply troubled company's current predicament is very complex, as various factors are responsible for the crisis. In order to restore the company back to normal functioning, these factors were studied and evaluated. A diagnostic survey was conducted to obtain data about current working conditions of company. Data from the survey were analyzed qualitatively and quantitatively to identify and evaluate the disruptive factors. Based on this analysis, problems in operational activities were identified and appropriate improvement actions (best practices) were proposed. Furthermore, the proposed improvement actions were assessed from a sustainability perspective to check their feasibility. The best practices framework was generalized to a three-step continuous improvement framework oriented around preparedness for future pandemic-like disruptions. The proposed framework may constitute an indication and set of best practices for consideration by other manufacturing companies that find themselves in a similar situation to the analyzed case study.
\end{abstract}

Keywords: COVID19; pandemic; diagnostic survey; manufacturing; best practices; Industry 4.0

\section{Introduction}

COVID-19 is an infectious respiratory system disease first recognized and described in Wuhan in central China in November 2019 [1], and it was characterized as a pandemic by the World Health Organization (WHO) on 11 March 2020 [2]. Currently, (13:04 CEST, 18 December 2020), there have been 9,979,447 confirmed cases of COVID-19, including 144,789 deaths, reported by WHO [3]. However, this is significantly underestimated and very uncertain due to reporting and testing procedure shortcomings, e.g., the number of infections in the US is estimated to be 3-20 times higher than confirmed cases [4]. With the second highest reported number of confirmed cases after the USA [5], the pandemic has taken a toll on almost every aspect of the 1.3 billion population in India. Considering the Indian population and Indian testing, reporting, and healthcare system, this also has to be considered to be an underestimate [6]. COVID-19 impacted all sustainability aspects all over the world, including economic, environmental, and social issues. The Indian economy is estimated to have contracted 23.9\% in the second quarter of 2020-2021 year to year with a 39.3\% economic contraction in the manufacturing industry [7], with a further $7.5 \%$ contraction of the Indian economy in the third quarter of 2020-2021 with $1.7 \%$ economic growth in the manufacturing industry [8]. COVID-19 induced lockdowns resulted, which contributed to decreasing pollution and energy consumption [9-11], which is positive for environmental sustainability. On the other hand, there were numerous social 
risks reported, such as problems with healthcare services in areas other than COVID-19 treatment and mental diseases, e.g., an increase of self-harm rates [12]. Except a 50\% drop in rice production, micro, small, and medium enterprises surveyed by UNIDO in all other industries have come to a halt [13]. Pandemic impacts on economic sustainability are widely discussed, but those negative impacts will surely imply social consequences, and positive environmental impacts (and eventually social and economic impacts related to them-like lower incidence of lung cancer due to lower pollution) are just an effect of lockdown, and are not presumed to sustain for a longer period [14]. Due to COVID-19, most manufacturing companies had to reduce their operational activities, and some had to halt production. Making up for production time lost is impossible for many organizations. The pandemic's impact not only halted operations, but also exposed the shortcomings of whole supply chains in which companies participated [15]. Due to closing borders and suspension of airlines, lead times increased for all imported/exported goods, and in turn caused further downtimes [16]. Governmental lockdown has affected the livelihood of millions of workers in India, and this had a clear effect on the overall economy, and migration of workers from cities to rural areas added to the miseries of already struggling industry, while also increasing the risks of virus spread in rural areas, which are struggling with more healthcare deficiencies [17].

Query "COVID AND manufacturing" was searched in the Web of Science Core Collection database on March 19, 2021. The first 150 results, selected by the newest publication date, were screened. Only those reflecting managerial issues were considered for further analysis. There are many studies related to COVID-19 and manufacturing industries, but after abstract screening, only 15 were in the scope of considerations, as others related to medical issues, technology processes of vaccine production, etc. Therefore, the vast majority of studies are oriented around issues related to chemistry, pharmacology, manufacturing of vaccines, and organization of health services. In general, selected papers could be discussed in categories like:

- Studies related to supply chains in general-especially global supply chains, the need for decentralization and assuring interoperability, supply chains resilience (e.g., in automotive and airlines sectors, medication supplies) [18-24];

- $\quad$ Studies related to possible support from specific technologies (especially from Industry 4.0 toolset) to fight COVID-19-induced problems in manufacturing and supply chains, e.g., additive manufacturing (e.g., for rapid prototyping and decreasing new product development cycles, for supply chains), robotics [18,25-29];

- Studies oriented on impacts on sectors and industries and their supply chains on macro or mezzo economy levels, e.g., automotive and airlines, medications, power, food, and consumer electronics [19-21,30-33].

The above analysis shows that there is lack of analysis on micro level of specific manufacturing organization, i.e., case studies that give detailed insights into problems and enable careful diagnosis of a company. There were also no works found that approached finding generic managerial models to deal with pandemic issues in a manufacturing company.

The current situation has disrupted the entire manufacturing industry. To keep businesses afloat, many changes and precautionary measures had to be undertaken. Industries and authorities all over the world are preparing plans for post-pandemic recovery. Sustainability awareness is raised in those plans. Moreover, Industry 4.0 solutions are presented as a means to achieve a socio-economic restart and necessary improvement for future crisis preparedness [34]. Many weaknesses of current manufacturing systems were uncovered. This study is oriented to investigate impacts of COVID-19 and moving many activities to remote mode on the shopfloor of manufacturing companies. A case study of an Indian asphalt batch mixing plants manufacturer that encountered the crisis caused by the COVID-19 pandemic is presented. The crisis is dependent on multiple factors. The study investigated these disruptive factors and evaluated which of them had most impact on operational activities and the correlation amongst these factors. At the same time, the impact of working from home on aspects of operations at the asphalt batch mixing plant 
manufacturer was analyzed. Finally, a general framework and best practices are proposed to survive the pandemic and take counteractions to future risks. However, this framework still needs further verification, and a plan for this verification was built upon experiences from this research.

The remaining sections of this paper depict materials and applied methods (Section 2, including case and sample description, sampling methods, survey questionnaires, hypotheses for testing), results obtained (including data diagnostic survey, descriptive statistics, regression analysis, Spearman's ranks), discussion (Section 3, including best practices addressing problems emerged due to the pandemic, and proposal for generalized framework to address those problems), and conclusions (Section 5).

\section{Materials and Methods}

A single explanatory case study was performed. The company studied was Kaushik Cesan Equipment Pvt. Ltd. (Ahmedabad, India), a joint venture between Indian giant Kaushik Engineering Works and Turkey-based Cesan A.S., established in 2013 for the purpose of serving their worldwide client base with outstanding services in engineering, production, and manufacturing. Their methodology of production is make-to-assembly as the company produces modular segments of plant based on demand forecast. Depending upon needs, Kaushik Cesan serves a wide range of customers by facilitating plants of various designs and capacities ranging from 80,000-400,000 kg per hour [35]. An Indian manufacturer of asphalt batch mixing equipment for road construction located in Sanand Ahmedabad, Gujrat, was chosen for a case study. The research process started with a primary thesis that the operations at chosen organization were impacted by the disruptions caused by the COVID-19 pandemic. The thesis seemed obvious, however was additionally confirmed in a tele-interview with one of the production managers working in the organization. Furthermore, two online questionnaires were developed to collect the responses from employees and managers working at the company. Due to the specific nature of the study, the criteria used to select viable respondents (sample) for data collection were based on a composite non-probabilistic method of survey sampling [36].

From a broader perspective the sampling technique used was purposive sampling, as the best respondents to answer the questionnaire were employees working at the company. This might be justified due to the fact the employees have been working in the company during the COVID-19 period and have first-hand experience of changes and impacts in the company's operations. Furthermore, while choosing the sample, a homogeneous sampling technique was employed at two different levels. The first one was based on occupation level, access to information, and experience level; the survey was constructed in two parts (one intended for office workers and another intended to be filled by managers). On a second level, a homogeneous sampling technique was used, as respondents shared common traits/characteristics regarding the same experiences of working in the same company and sharing similar day-to-day life experiences in this COVID-19 period.

To get the data from the survey that can be statistically analyzed, convenience sampling was used. The fact that the intended study outcome was of high interest to employees working at the firm justifies two online questionnaires being deployed for the purpose of data collection from employees.

Due to the presence of many variables impacting the operational activities at the firm, the nature of data collected was both qualitative and quantitative. In addition, both types of data were collected. Two questionnaires designated for employees and managers consisted of 24 and 32 questions, respectively, with a total of six question types, short response questions, multiple choice questions, checkboxes, discrete visual analog scale questions, Likert items, and detailed (long, qualitative) answer questions. Furthermore, the questionnaire developed for staff had three sections, and in case of managers, there was an additional fourth section.

All the data were collected remotely due to multiple reasons. The first and most important was safety during this ongoing pandemic, a second reason was the time constraints 
as online questionnaires are a fast and low-cost means of data collection. The links to questionnaires constructed in Google Forms were sent out on 20 September 2020. Google Forms was sufficient as an important assumption of the survey was its simplicity due to the fact it was addressed to interviewees busy in a pandemic period. Responses were collected automatically in until 30 September 2020. Respondents filled in questionnaires online on themselves. During this of time 45 employees working in different departments, including five managers. The structure of respondents reflected proportions of staff in the considered company. The majority of respondents $(65 \%)$ were employed in one of three core operational departments, i.e., operations ( $40 \%$ ), quality (17.5\%), production planning $(10 \%)$, logistics $(7.5 \%)$. Detailed structure is presented on Figure 1. Respondents from operations department were shift supervisors, clerks, controller, analysts, inspectors, assistants. It is worth to see that among other positions (not from operations, logistics, quality departments) it is only forecast analyst and marketing supervisor who is not cooperating with operations on an hourly basis.

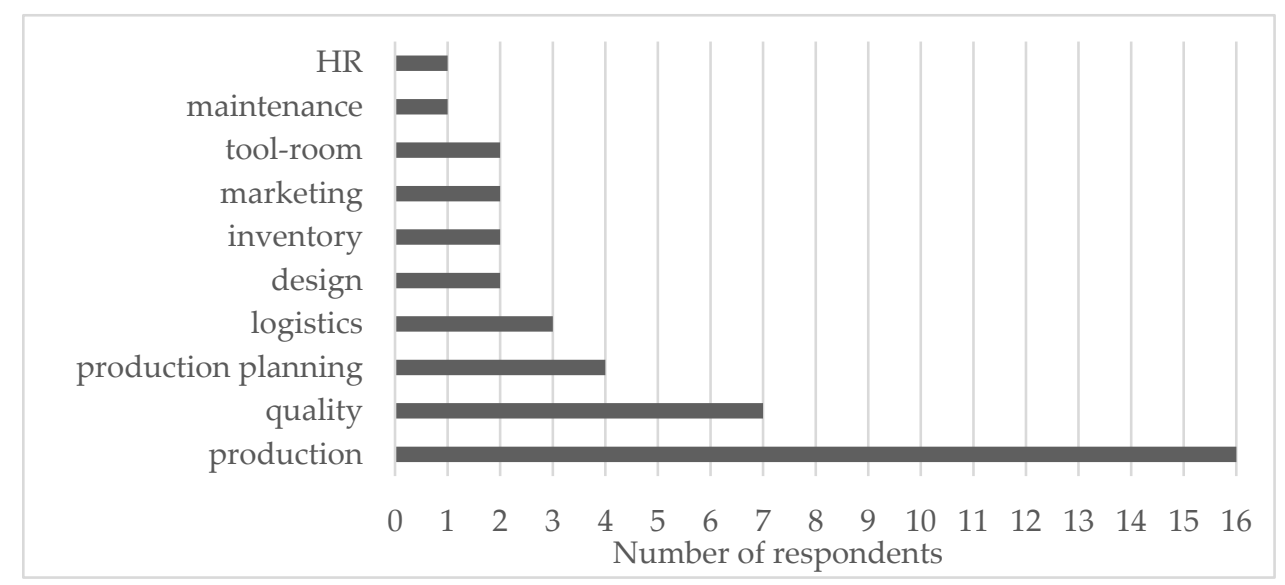

Figure 1. Sample structure.

Additionally, managers from all five departments existing in the organizational structure were surveyed (i.e., quality, production, planning, logistics and human resources). They also filled in questionnaires online on themselves. Data collected were raw and mixed i.e., ordinal and numeric types of responses were present on the data sheet. Furthermore, the data were cleaned, pre-processed and rearranged for analysis. The first three sections of both questionnaires-Appendix A intended for employees and Appendix B intended for managers-consist of similar questions and delivered no significantly different results. Therefore, responses from both groups were treated collectively in further considerations.

The data collected from both questionnaires (Appendices A and B ) were analyzed to test the following hypotheses:

- Disruption caused by the pandemic had impact on general operations, availability of raw materials, availability of transportation, availability of workforce, shortage in demand(orders), insufficient production to fulfil demand, increase in machine failures, increase in workload, decline in working hours and the restrictions imposed by local/central law authorities had an impact on operations;

- Remote working has some benefits like flexible schedule, working from any location, no commute, more time spent with family etc.;

- There are some difficulties associated with remote work like team collaboration, media distractions, children, spouse and/or partner, pets, roommate(s), staying motivated, fewer mental stimuli, reliable internet connection etc.;

- There are correlations between aspects of remote work (benefits and difficulties) and impact on operational activities caused by the pandemic (these will be discovered through the diagnostic survey). 
Descriptive statistics were generated from responses and inferences about samples were made. Descriptive statistics were prepared in a spreadsheet using data analysis tool pack and pivot tables. To check the variance and significance of different variables in the second section of the questionnaires, multiple linear regression was performed in the spreadsheet. In addition, the correlation of variables impacting operational activities during the pandemic was analyzed. Furthermore, correlation of aspects of remote work with impact on operational activities were analyzed using IBM SPSS statistics. Due to response data type being ordinal and nominal/categorical, Spearman's ranks correlation was used.

The extensive data analysis pointed out the problems with current functioning of the organization. To rectify these problems, some improvement activities/plans were proposed. Furthermore, these improvement plans formed the basis of a general good/best practices framework, showing how to survive, stabilize, and sustain the disruptions caused by the pandemic.

The validity and sustainability of the proposed framework were discussed throughout the virtual focus group interview. The focus group consisted of senior operation managers from various industries as well as research experts of sustainability topics.

Figure 2 depicts the full research procedure discussed above.

\begin{tabular}{|c|c|c|c|}
\hline $\begin{array}{l}\text { Introductory tele-interview } \\
\text { Confirmation of primary } \\
\text { assumption, the need for } \\
\text { further investigation, } \\
\text { defining main requirements } \\
\text { for diagnostic survey }\end{array}$ & \begin{tabular}{|l|} 
Data collection \\
On-line survey \\
Purposive homogeneous \\
and convienience sampling \\
Composite non- \\
probabilistic sampling
\end{tabular} & $\rightarrow \begin{array}{l}\text { Data analysis } \\
\text { Quantitave } \\
\text { and qualitative } \\
\text { analysis } \\
\text { Correlations of } \\
\text { variables }\end{array}$ & $\begin{array}{l}\text { Best practices and generlised } \\
\text { framework } \\
\text { State-of-the-art } \\
\text { Proffesional industrial webinars } \\
\text { dedicated to COVID-19 problems } \\
\text { Focus group interview }\end{array}$ \\
\hline
\end{tabular}

Figure 2. Research procedure.

\section{Results}

\subsection{Descriptive and Inferential Statistics}

For questions where a linear differential scale was introduced (Appendices A and B), the extent of impact of various factors was diagnosed. Therefore, a six-point scale of impact was designed $(0 \%, 20 \%, 40 \%, 60 \%, 80 \%$, and $100 \%)$. Any positive value of the arithmetic mean of responses collectively would have suggested that there was some impact of variable (factor), and the hypothesis would be confirmed. Figure 3 illustrates collective arithmetic means of responses from the survey sample.

It is evident from Figure 3 that the collective arithmetic means of the responses on the extent of disruptions caused by various factors on operational activities from the survey sample are all positive. This shows the disruptions caused by the pandemic had an impact on general operations, availability of raw materials, availability of transportation, availability of workforce, shortage in demand (orders), insufficient production to fulfil demand, increase in machine failures, increase in workload, and decline in working hours, and the restrictions imposed by local/central law authorities had an impact on operations; hence, the hypothesis was confirmed.

Figure 4 illustrates the relative frequency distribution of responses to "Top benefits of remote work".

The criteria for hypothesis determination to question 21 (Appendices A and B) were based on the responses of employees; more than $50 \%$ of respondents agreeing to the questions were accepted, otherwise they were rejected. All respondents reported a flexible schedule, $94 \%$ no commute, and $91 \%$ more time spent with family and working from any locations to be the top benefits of working from home; hence, we confirm our second hypothesis. 


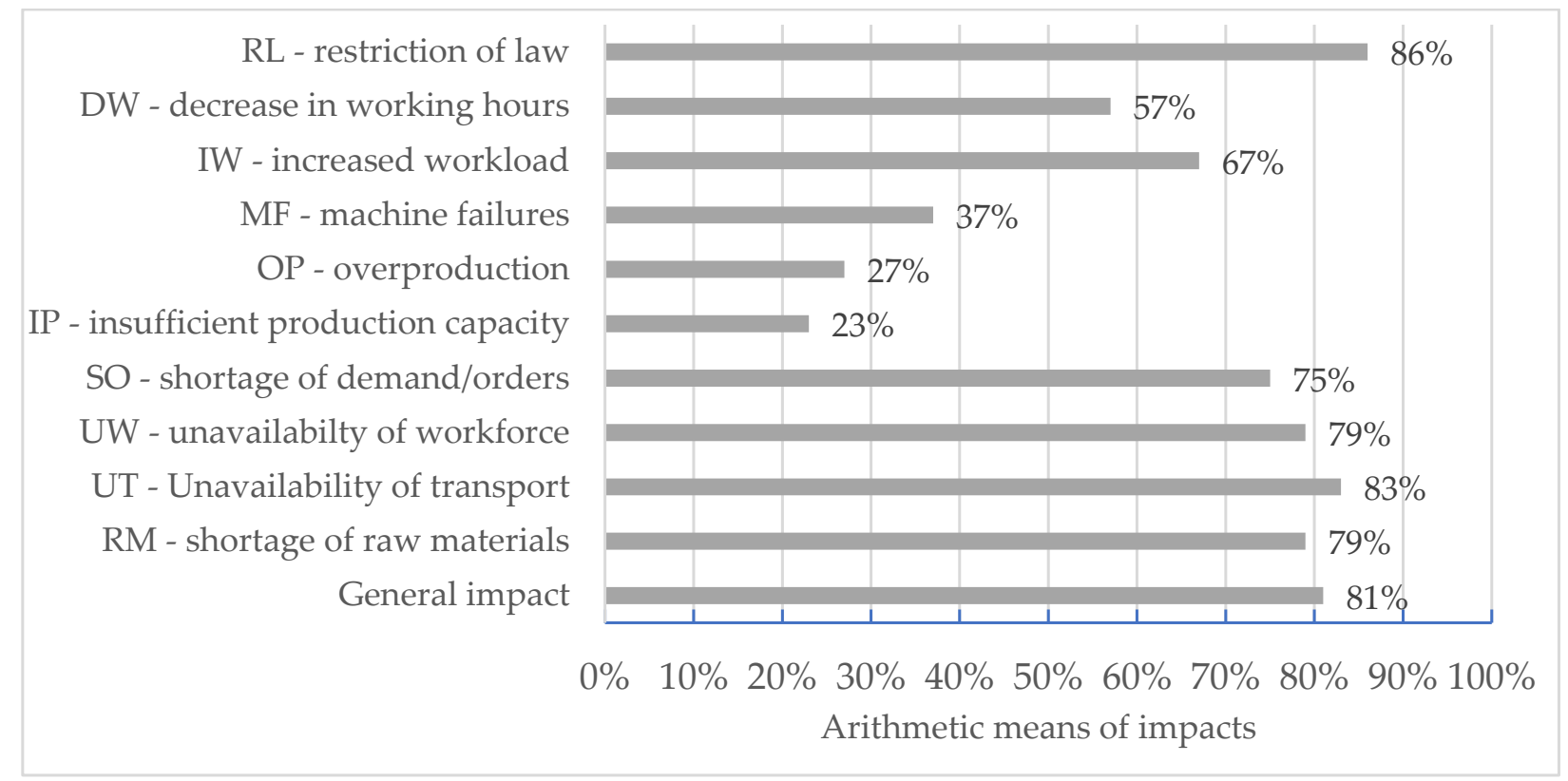

Figure 3. Collective arithmetic means of responses from sample on the extent of impacting factors.

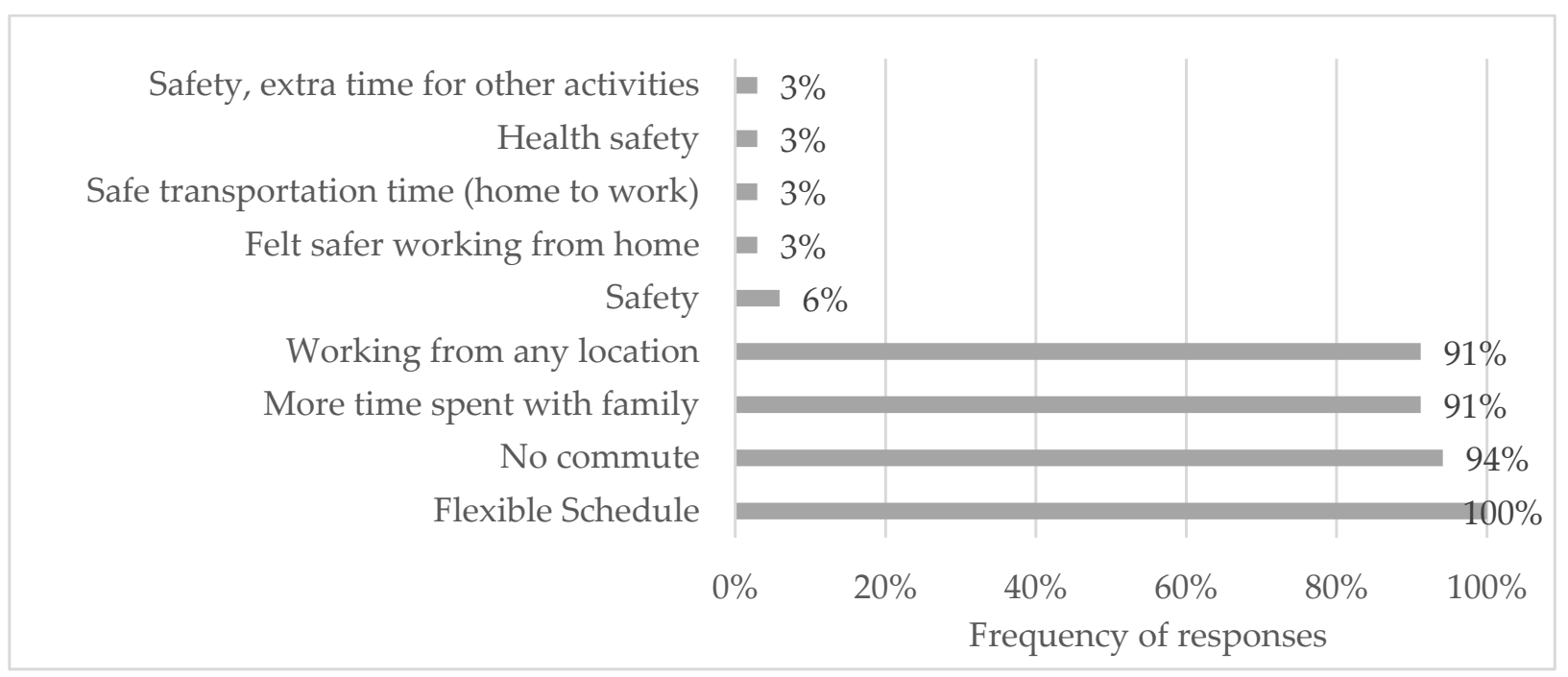

Figure 4. Relative frequency distribution of responses to "Top benefits of remote work".

Figure 5 illustrates the relative frequency distribution of responses to "Top struggles associated with remote work". Again, the criteria for hypothesis determination to question 22 (Appendices A and B) were based on response of employees; more than $50 \%$ of respondents agreeing to the questions were accepted otherwise rejected. At least $50 \%$ of respondents reported collaboration/communication, lack of necessary equipment, fewer mental stimuli, staying motivated, distractions from media, spouse/partner, and children to be the struggles of working from home, but reliable internet connection, loneliness, pets, and roommates were reported by less than $20 \%$. Hence, the third hypothesis is partially confirmed after taking these factors out of consideration. 


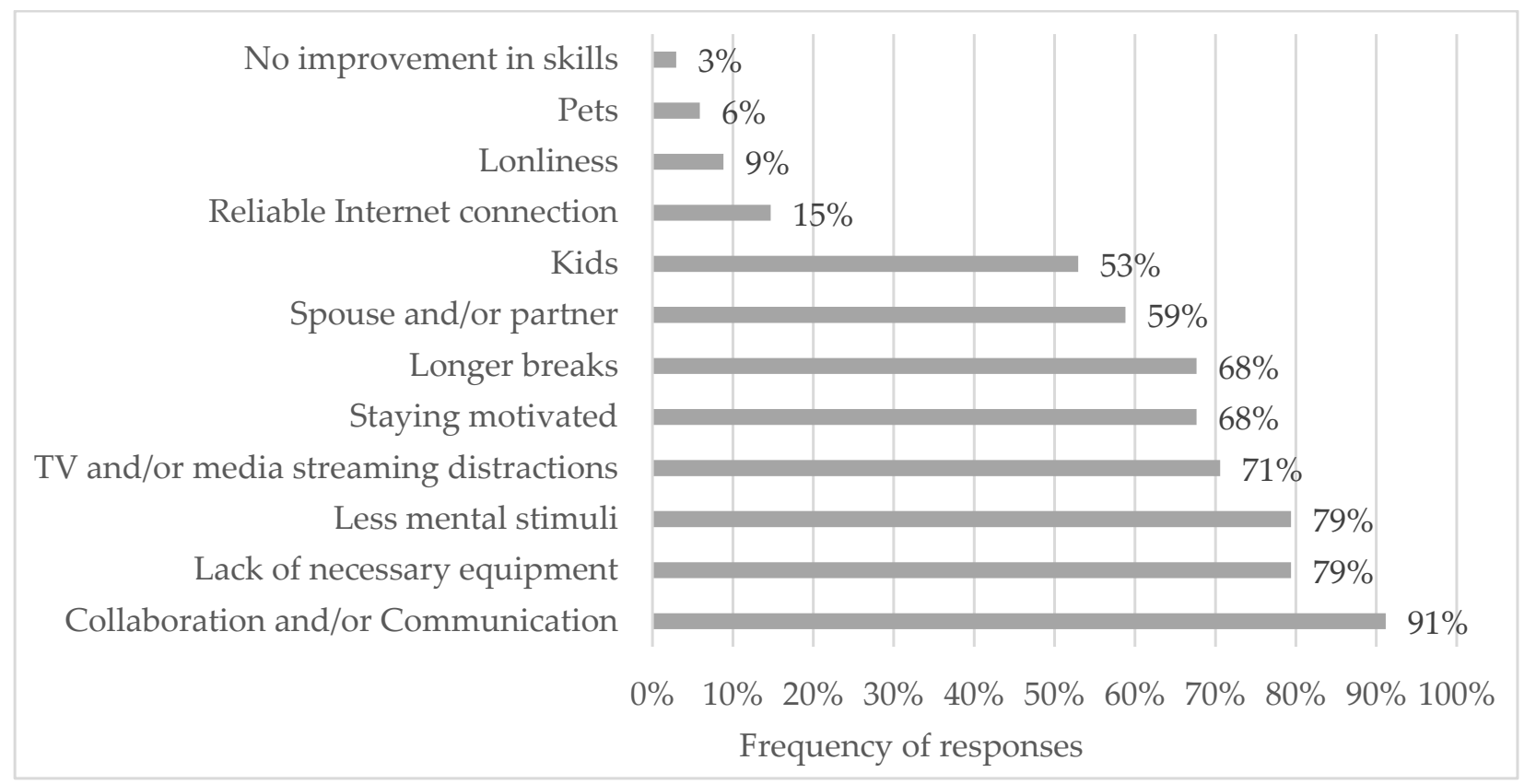

Figure 5. Relative frequency distribution of responses to "Top struggles associated with remote work".

\subsection{Regression}

Multiple linear regression was performed to see the impact of independent variables on the dependent variable. The first question in the third section of the questionnaire (Appendices A and B, question 9) was treated as dependent variable, and the following ten questions (Appendices A and B, questions 10-19) were considered as independent variables. By the principle of linear regression, an attempt was made to model the relationship between certain variables by fitting a linear equation to data collected (Equation (1)).

$$
\begin{gathered}
\hat{y}=a(R M)+b(U T)+c(U W)+d(S O)+e(I P)+f(O P) \\
+g(M F)+h(I W)+i(D W)+j(R L)+k
\end{gathered}
$$

where:

- $\quad a, b, c, d, e, f, g, h, i$, and $j$ are the coefficients of consecutive independent variables;

- $\quad$ RM (shortage of raw materials), UT (unavailability of transport), UW (unavailability of workforce), SO (shortage of demand/orders), IP (insufficient production capacity), OP (overproduction), MF (machine failures), IW (increase in workload), DW (decline in working hours), and RL (restriction of law) are the values of independent variables;

- $\quad \hat{y}$ is the predicted value of dependent variable;

- $\mathrm{k}$ is the intercept.

The objectives were to find the coefficient of determination $\left[\mathrm{R}^{2}\right]$, i.e., the proportion of the variance in the dependent variable general impact on the company that is predictable from the independent variables in the second section of the survey, and to see the significance analysis, which is the likelihood of interdependence of variables (Table 1). Furthermore, to see the significance of each independent variable individually, a model was developed in the spreadsheet. In this model, the independent variable was assigned each possible value $(0 \%, 20 \%, 40 \%, 60 \%, 80 \%$, and $100 \%)$ to determine prediction of the output variable, while all other independent variables were given their observed average values. Figure 6 illustrates the predicted significance of impacted variables individually. 
Table 1. Regression statistics.

\begin{tabular}{cccccc}
\hline Name & Multiple R & R Square & $\begin{array}{c}\text { Adjusted R } \\
\text { Square }\end{array}$ & Standard Error & Observations \\
\hline Value & 0.61 & 0.37 & 0.17 & 0.07 & 44.00 \\
\hline
\end{tabular}

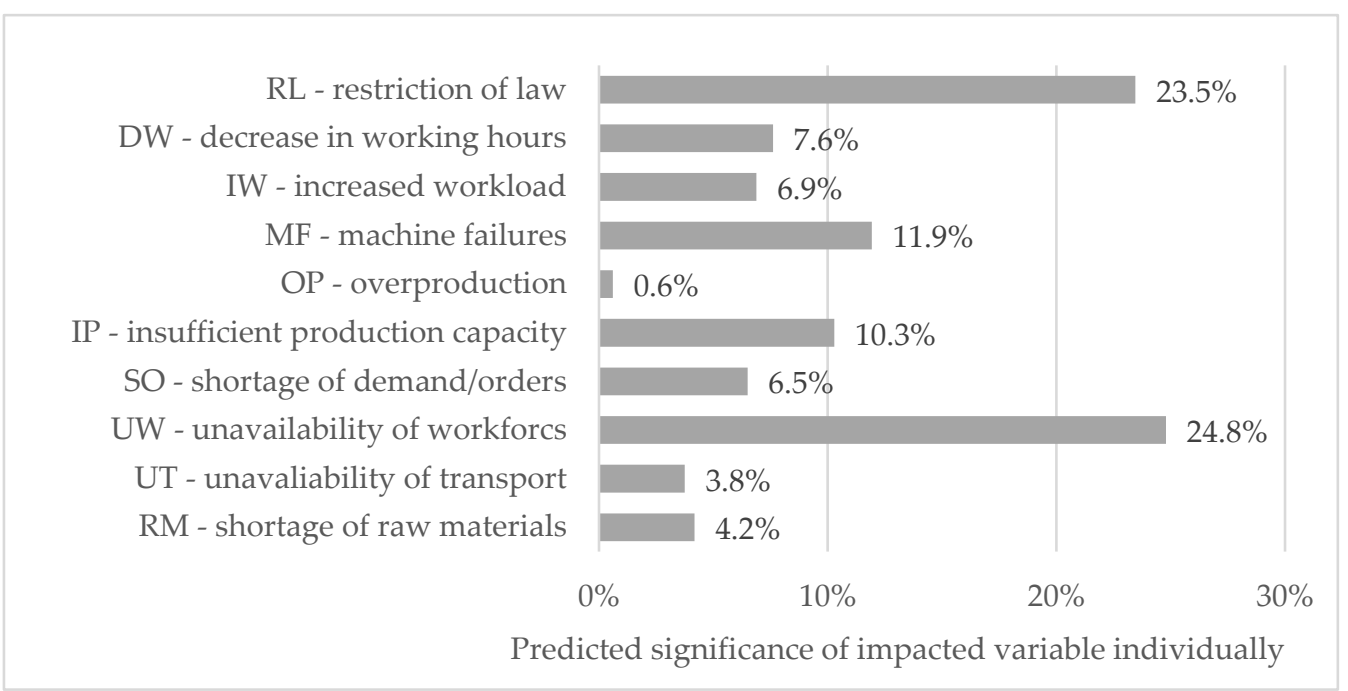

Figure 6. Predicted significance of impacted variables.

\subsection{Spearman's Ranks}

To see the correlation of disrupted variables, Spearman's ranks were identified for these factors. Due to the response data type being ordinal or nominal/categorical, Spearman's ranks correlation was used. In Appendix C, the correlation coefficients can be seen. Some important correlations among aspects of operational activities are given in Table 2. Furthermore, correlation of aspects of operational activities and top benefits of remote work were analyzed. Again, the Spearman's ranks were calculated. Appendix C illustrates the calculated values of correlation coefficients. Significant correlations found are shown in Table 3. In addition, correlation of top difficulties of remote work and aspects of operational activities were analyzed. Appendix C contains Spearman's ranks. Some important correlations found are shown in Table 4.

Table 2. Correlations among aspects of operational activities.

\begin{tabular}{|c|c|c|}
\hline & Positive & Negative \\
\hline $\begin{array}{l}\infty 0 \\
0 \\
0 \\
\dot{0}\end{array}$ & $\begin{array}{l}\text { Overproduction and lack of raw materials } \\
\text { Overproduction and shortage in demand } \\
\text { Machine failures and lack of workforce }\end{array}$ & $\begin{array}{l}\text { Insufficient production and overproduction } \\
\text { Increased workload and shortage of orders } \\
\text { Overproduction and increased workload }\end{array}$ \\
\hline 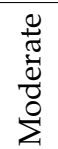 & $\begin{array}{l}\text { Shortage of raw materials and } \\
\text { unavailability of transport }\end{array}$ & $\begin{array}{c}\text { Lack of raw materials and machine failures } \\
\text { Unavailability of transport and machine } \\
\text { failures }\end{array}$ \\
\hline
\end{tabular}

It is evident from the data in Appendix C (Tables A1-A3) and the above data that there are significant correlations between aspects of remote work (benefits and difficulties) and impact on operational activities caused by the pandemic. Hence, we confirm our third hypothesis. 
Table 3. Correlations among operational activities and top benefits of remote work.

\begin{tabular}{|c|c|c|}
\hline & Positive & Negative \\
\hline $\begin{array}{l}0.0 \\
\tilde{D}^{ \pm}\end{array}$ & $\begin{array}{c}\text { Unavailability of transport and flexible schedule of work } \\
\text { Shortage of orders and flexible schedule } \\
\text { Shortage in demand and work from any location } \\
\text { Insufficient production and working from any location } \\
\text { Shortage in demand and no commute } \\
\text { Unavailability of transport and more time spent } \\
\text { with family } \\
\text { Shortage of raw materials and more time spent } \\
\text { with family } \\
\text { Shortage in demand and more time spent with family }\end{array}$ & $\begin{array}{l}\text { Restrictions of law and } \\
\text { flexible schedule } \\
\text { Restrictions of law and more } \\
\text { time spent with family } \\
\text { Increased workload and more } \\
\text { time spent with family }\end{array}$ \\
\hline $\begin{array}{l}\frac{0}{\pi} \\
\frac{\pi}{0} \\
\frac{0}{0} \\
\sum\end{array}$ & $\begin{array}{l}\text { Insufficient production capacity and flexible working } \\
\text { schedule }\end{array}$ & $\begin{array}{c}\text { Flexible work and } \\
\text { increased workload } \\
\text { Restrictions of law and } \\
\text { no commute } \\
\text { Restrictions of law and work } \\
\text { from any place }\end{array}$ \\
\hline
\end{tabular}

Table 4. Correlations among operational activities and top struggles of remote work.

\begin{tabular}{|c|c|c|}
\hline & Positive & Negative \\
\hline $\begin{array}{l}\text { की } \\
\text { है } \\
\text { के }\end{array}$ & $\begin{array}{l}\text { Unavailability of transport and } \\
\text { collaboration/communication } \\
\text { Shortage in demand and } \\
\text { collaboration/communication } \\
\text { Insufficient production capacity and } \\
\text { collaboration/communication } \\
\text { Lack of motivation and insufficient } \\
\text { production capacityLack of necessary } \\
\text { equipment and insufficient production } \\
\text { capacityShortage in demand and } \\
\text { longer breaks }\end{array}$ & $\begin{array}{c}\text { Restrictions of law with } \\
\text { communication/collaboration } \\
\text { Media streaming distractions with fewer } \\
\text { mental stimuliIncreased workload with: } \\
\text { distractions from spouse/partner } \\
\text { distractions from children } \\
\text { Unavailability of workforce with: } \\
\text { media distractions and lack of equipment, } \\
\text { loneliness, and } \\
\text { shortage of raw materials }\end{array}$ \\
\hline 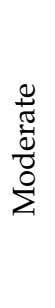 & $\begin{array}{l}\text { Insufficient production capacity and media } \\
\text { streaming distractions } \\
\text { Fewer mental stimuli and insufficient } \\
\text { production capacity } \\
\text { Decline in working days and spouse/partner } \\
\text { distractions } \\
\text { Shortage in demand/orders and distraction } \\
\text { from children }\end{array}$ & $\begin{array}{l}\text { Increased workload with collaboration } \\
\text { of workers }\end{array}$ \\
\hline
\end{tabular}

\subsection{Qualitative Analysis (Significance of Disruptive Factors)}

To evaluate the most disruption-causing factor according to respondents from the third section of the questionnaire (Appendices A and B), responses were qualitatively analyzed in a spreadsheet. Arithmetic means of responses were calculated for all ten diagnostic variables. Figure 7 shows the relative significance of variables. 


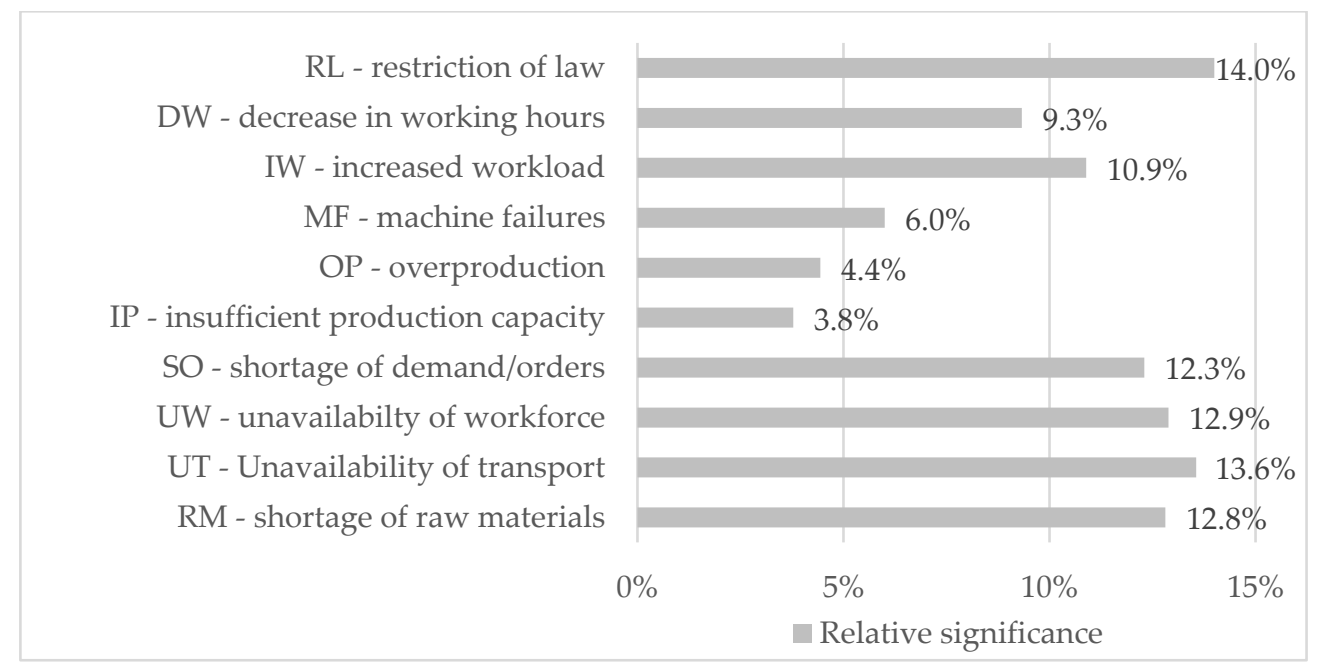

Figure 7. Relative significance of variables.

\section{Discussion}

\subsection{General Findings}

Although the hypotheses were designed just to confirm the validity of disruption causing factors, the scales for responses of the third section of the questionnaire (Appendices A and B) were designed in such a way that the impact of these factors could be evaluated.

While performing regression, responses from both surveys were taken into account, and data from both surveys were analyzed collectively. $R^{2}$ value equals 0.37 for multiple regression, which is fair. The value could be explained by the sample being the actual population, with the survey treating responses from every participant equally irrespective of experience and field of expertise.

The data in results (Figure 5) evidently suggest unavailability of the workforce had highest impact of $24.79 \%$ on predicted value of general impact on operational activities of the studied company, which is followed by impact due to restrictions imposed by local authorities at $23.45 \%$. In addition, machine/equipment failures and insufficient production hindering operational activities are in double digits at $11.93 \%$ and $10.29 \%$, respectively. Furthermore, decline in working hours, increased workload, and shortage of orders were reported to be impacting operational activities at $7.61 \%, 6.89 \%$, and $6.50 \%$, respectively. The significance of raw material shortage, unavailability of transport, and overproduction have had least impact according to respondents, with each factor signifying $4.18 \%, 3.75 \%$, and $0.60 \%$, respectively.

\subsection{Qualitative Analysis}

From the results, disruptions caused by the pandemic had an impact on general operations, availability of raw materials, availability of transportation, availability of workforce, shortage in demand (orders), insufficient production to fulfil demand, increase in machine failures, increase in workload, and decline in working hours, and the restrictions imposed by local/central authorities had an impact on operations, and these problems need to be rectified. In this regard some improvement actions in policies, improvements in shopfloor activities, improvements in office activities, and improvement activities on the edge of the office and shopfloor were proposed in further subsections of the Discussion section.

\subsection{Problems Identified and Improvement Action Best Practices}

\subsubsection{Unavailability of Raw Materials}

Improvement action(s): supply chain reorganization, increased storage capacity, and contract with multiple regional suppliers. 
Supply chains should be shifted from globalized to regionalized. Kaushik Cesan should switch from global trade partners to local vendors to obtain a continuous adequate supply of raw materials needed to carry out manufacturing processes. A larger stock of raw materials inventory in these unpredictable times would ensure a greater buffer for scarcity of raw materials needed to carry out production operations. In addition, the larger raw material stock will ensure continuity of production in the case of a lockdown imposed by governmental authorities. Switching to regional suppliers can help to solve problems due to restrictions imposed by local authorities in the form of lockdowns and closing of international borders as the material movement will be much easier in regional supply chains. In addition, the supply of raw materials from regional vendors would be faster during crisis periods to ensure continuous manufacturing activities $[37,38]$.

\subsubsection{Unavailability of Transport}

Improvement action(s): Reorganization of supply chains, Industry 4.0 initiatives.

Justification: The supply of raw materials from regional vendors would be convenient during crisis periods, ensuring continuous manufacturing activities. In addition, using a regional supply chain will avoid the need for international transportation of supplies and goods, altogether sidestepping this large obstacle. Autonomous smart vehicles can serve as transportation in these times without imposing any threat to community safety.

\subsubsection{Unavailability of Workforce}

Improvement actions(s): Accommodation of workers in the vicinity of factory premises, ensuring safety in the workplace, improving skill and morale of workers and automating production operations.

Justification: In context of COVID-19 related problems, accommodations for the workforce in the vicinity of workplace (a protective bubble) would be fruitful [39]. As during governmental lockdowns, there would be no interruption in production. Additionally, it would be beneficial safety-wise, as there would be less chance to spread disease, because workers would have less contact with outside surroundings. Training the workforce will improve the workers' productivity and morale. The best way to go about it is by crosstraining employees. Cross-training workers could be perfect in these times of crisis, as there would be multiple workers to carry out a specific job [40]. Automated machining will reduce the need of workers, as only few workers will be needed to monitor the operation, which can be also done remotely.

\subsubsection{Surge in Demand}

Improvement actions: Industry 4.0 initiatives, advanced equipment with trainings.

Justification: To keep up with demand surges in market, there needs to be better visibility and end-to-end transparency of goods in supply chains. Advanced software and big data analysis will help to forecast the consumer projections, and production will be planned accordingly, hence reducing insufficient production or overproduction. Nerve center and control tower approaches can be used to increase transparency across supply chains [41].

\subsubsection{Increased Machine Failures}

Improvement action(s): Preventive maintenance, standardized operations, engaging workers, and ensuring collaboration.

Justification: Preventative maintenance will reduce machine/equipment failures and increase the life of machines [42]. Additionally, production should be planned in such a way that inertia of electro-mechanical components is maintained with minimum pauses [38]. Standardizing operations would ensure less downtime, consistent quality, and optimum production. With a standardized operations manual, workers need to follow the checklist designated at each workstation, which would reduce machine/equipment failures and reduce the need of opinions from specialized personnel at every instance. 


\subsubsection{Increase in Workload}

Improvement action(s): Automated machining, providing proper work equipment, and explaining goals.

Justification: Automated machining will reduce the workload of employees significantly, as it will be sufficient to just monitor and calibrate the systems. Proper hardware and software would enable employees to perform tasks much more easily and efficiently. In addition, without knowing goals and objectives, employees can spend a substantial proportion of their workday pursuing the wrong objectives, which can decrease productivity and profit.

\subsubsection{Restrictions Imposed by Local Authorities}

Improvement action(s): supply chain reorganization, accommodating workers in vicinity of factory, and reorganizing the workplace.

Justification: Reorganization of supply change from international to regional supply chains can help to solve the problems caused due to restrictions imposed by local authorities in the form of lockdowns and closing of international borders, as the material movement will be much easier in regional supply chains [37]. Accommodating workers in the vicinity of factory premises will ensure the availability of workers to carry out operations like normal functioning, which will nullify the impact due to restrictions imposed by local authorities. Reorganization of the workplace is mandatory in accordance with governmental guidelines. In addition, reorganizing the workplace will improve the safety of workers and the workplace, which is vital in contemporary times to ensure continuity of operations.

\subsection{Survive-Stabilize-Sustain: $3 S$ Generalized Framework for the Manufacturing Industry}

During the planning and implementation of improvement actions proposed in the previous section, the following $3 \mathrm{~S}$ framework should be considered (Figure 8).

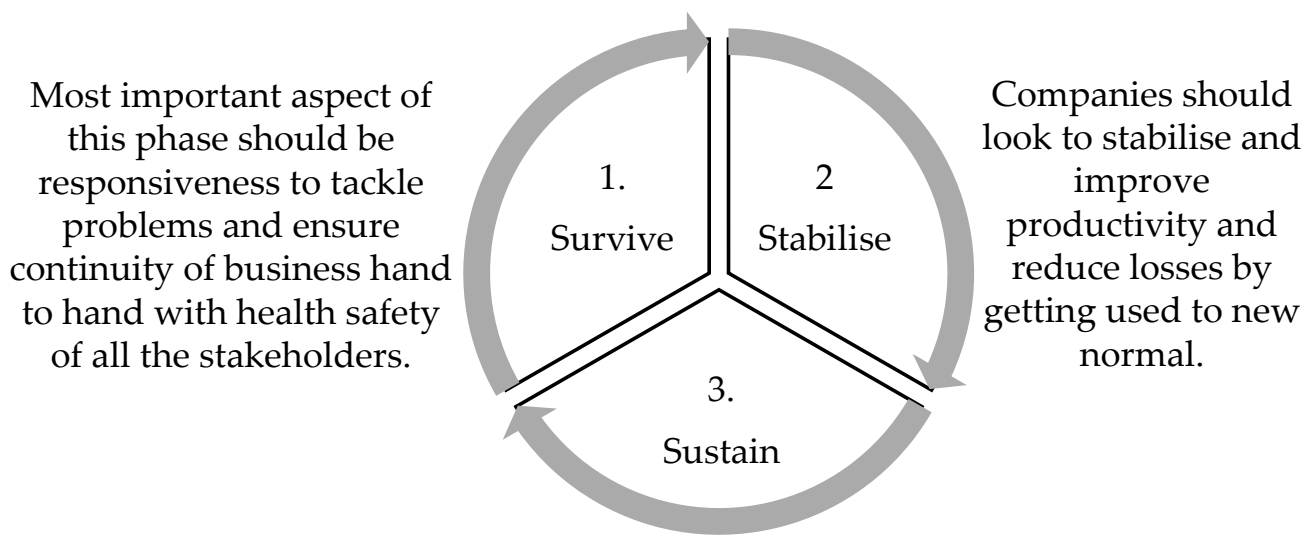

By adopting best practices and continuously improvement, businesses should be able to control the processes inspite all the disruption caused by pandemic.

Figure 8. Generalized $3 S$ framework of good/best practices for manufacturing industry.

The following framework is based on an extensive literature review [26,37,43-46], proposed improvement actions from this study (which were based on results from questionnaires), and webinars [38,47-50] held in context of the current state of the manufacturing industry.

Survive

The first phase of the improvement plan is to keep business afloat and avoid bankruptcy while ensuring the health and safety of all stakeholders. In this phase, the production capacity should be kept low initially. 


\section{Worker safety}

A significant proportion of employees should be present on the factory floor to carry out operations for the manufacturing company. Strict measures should be taken to ensure, at this phase, the safety of workers and the workplace. Employees should be registered with regular temperature control on entry into factory premises. The workplace should be sanitized in a timely manner, and masks should be compulsory. In addition, there should be safety trainings on how to maintain physical distance in the workplace and avoid the spread of the virus [51].

- Analyze internal and external factors

Analyzing the state of affairs in the company is vital initially for the company. The analysis should provide insight into all factors (internal and external) contributing to disruptions caused by the pandemic. It will give managers information about inbound and outbound supply chains, current functionality of the internal production system, customer projections, market trends, etc.

\section{- Research}

Once the factors hindering operations are analyzed, it is time for research and testing the alternatives by developing models and simulating each possible scenario. The results of simulations should be evaluated, and best ways to tackle problems faced by company should be adopted.

- Readjust operations, workplace, and supply chains

The workplace should be reorganized based on research and guidelines provided by governmental regulations. Production systems should be readjusted to the current needs of the market. Production planning should be based on results from analysis of customer projections and availability of raw materials. The supply chain should be reorganized according to feasibility and availability of material flow.

- Facilitate remote work

For a manufacturing company, a significant amount of the workforce should be present on the production factory floor, but still, for a majority of employees, remote work is possible. Working remotely should be promoted during this crisis in order to ensure employees' safety and wellbeing. However, the employees working remotely should be properly equipped with all the necessary means to carry out their work efficiently and easily. In addition, proper communication lines should be set up in order to ensure smooth running of operations without being face to face.

\section{Stabilize}

In the second phase, companies should look to stabilize and improve productivity and reduce losses by getting used to the new normal.

\section{- Help lagging partners}

Once the internal systems are readjusted or replaced, external dependencies should be focused on. A swift response to the crisis should be offered by providing aid to struggling partners to ensure business continuity and prevent further losses. The aid can be financial loans (advance payments) to partners who are struggling or non-financial, such as sharing information or implementing best practices to reduce coronavirus damage.

- Train workers and explain new adjustments

With all the replacements/readjustments in the workplace, the engineering department should train workers and explain new goals and priorities of every adjustment to their work schedules. In these times of crisis, cross-training workers should be done, as there would be multiple employees to perform a specific job that can reduce downtime during a decrease in the workforce. Without knowing goals and objectives, employees can spend a substantial proportion of their workday pursuing the wrong objectives, which can 
decrease productivity and profit. Through establishing clear and realistic objectives with employees, proper management can therefore significantly improve production during these times.

- $\quad$ Standardize operations

Office workers should standardize each and every operation for maximum efficiency after making changes to the production system in accordance with the prevailing conditions. Engineers and process designers should keep a checklist on the shop floor and train employees to follow that task. Reduced downtime, consistent quality, and optimum production can be achieved by standardizing operations.

- Improve workers' morale

Management should encourage employees to make small changes in their respective processes in these uncertain times when most of the staff are working remotely without seeking expertise from engineers for every minor adjustment. This can help to improve modified processes quite quickly and build a strong sense of trust among employees and executives. Improved employee morale would lead to higher productivity and increase the ability of staff to work as a team.

- Collaboration and communication

In these times of uncertainty, it is vital for management to ensure collaboration of employees to perform better. Employees working remotely should have a viable communication channel for explaining procedures to shop floor workers and vice versa. The communication channel should also provide shop floor workers with the ability to report unusual machine behavior to specialists quickly, so that problems can be quickly corrected with minimum downtime.

3. Sustain

In the third phase, adopting best practices and continuous improvement should enable businesses to control the processes in spite all the disruption caused by pandemic.

- Elasticity and responsiveness

Each operation, readjustment, and change should be monitored and assessed continuously; if there are problems caused due to external factors, managers should be responding to situations quickly. Being agile in these times is vital; every decision is time sensitive. Therefore, management should always be quick to respond to disruptions along the way.

- Keep on improving

Even if the company is performing well after readjustments/changes made during the first/second phase, it is vital for business to keep on improving continuously. Managers should be taking feedback from all stakeholders like customers and employees and keep on developing best practices, processes, and procedures.

- Creativity

During these times, it is important to nurture creativity, as the situation is very unpredictable. Managers should encourage all stakeholders to give their opinions on ways to proceed. Creativity will improve the morale of employees and help them in personality development, which will add long-term value to the company.

- Process control

Control the outcome of each and every process and make sure every adjustment/change implemented is economically, socially, environmentally, and sustainably feasible.

\subsection{Sustainability Assessment of Proposed Improvement Actions}

In order to check the sustainability of the overall framework of best practices, proposed improvement actions were assessed according to the triple bottom line paradigm (economically, environmentally, and socially). 
Environmental assessments (Tables A4 and A5 in Appendix D) indicate negative impact on environment, but the magnitude of all the impacts will be relatively low, and also the significance of impact will not be any different than the current impact on the environment due to operational activities at the company. In addition, all assessments indicated that the negative impacts on environment are reversible, and once the conditions go back to normal, these actions can be re-assessed. Furthermore, the impact on employees' occupational health is positive in all cases. Hence, the company could go forward with proposed improvements from the environmental perspective, but more broadly, the general environmental impact of best practices framework should be assessed as neutral.

Table A6 clearly indicates that improvement actions will improve employees' mental health and morale, improve their skills, contain the spread of the virus, reduce work stress, reduce anxiety regarding the pandemic, and give employees working remotely an opportunity to spend more time with their families in these uncertain times. The best practices framework and improvement actions proposed thus have a positive impact from the social perspective.

To assess the overall feasibility of improvements, the impact of the proposed activities was confronted with the United Nations Sustainability Development Goals (SDGs) [52]. Table A7 shows that all the proposed improvement activities have a positive impact on at least one of the 17 SDGs. Hence the improvements are feasible from a sustainability perspective.

\section{Conclusions}

This study clarifies the aspects of the manufacturing industry that were impacted by the pandemic. According to respondents, restrictions imposed by local authorities have had the highest impact on operational activities, followed by unavailability of transport and unavailability of workers; after that, scarcity of raw materials and shortage in demand were reported to have highest significance. In addition, increased workload and decrease in working days have had significant impact, although lower than the above-mentioned factors. Finally, increase in machine failures, overproduction, and insufficient production to fulfil demand, respectively, have had an impact on operational activities. Although the magnitude of disruptive elements is specific for the company under observation, the study gives a brief idea of the intensities of impacts caused by several factors in the manufacturing sector in India.

The study also identifies the top benefits associated with telework, which are the flexible schedule, working from any location, no commute, and more time spent with family. In addition, the top drawbacks the employees had to face while working remotely for Kaushik Cesan were identified as collaboration/communication, lack of necessary equipment, fewer mental stimuli, staying motivated, distractions from media, spouse/partner, and children. Limitations of this study are related mostly to the fact that it is single case study, and sampling was convenience sampling with a not very numerous sample (39). These aspects can be generalized for the whole industry and incorporated in future workplace models. In order to achieve this goal, the research plan resulting from the analyzed case was developed. The framework proposed in this research needs further verification. Such research will include analysis of other industries as well as experiences from other countries. The plan includes ten manufacturing companies from Poland, Japan, and Turkey, and from different industries, e.g., fast moving consumer goods, automotive, cosmetics, sheet metal goods, and ironworks. All of them will be approached using the verified methodology presented in this article. Samples chosen for surveys will consist of workers directly involved in shopfloor manufacturing operations as well as their surroundings, like tool-shops, production planning, internal logistics, warehousing, supplies and deliveries, etc. The final generalization will be based on qualitative multiple case study analysis and quantitative statistical analysis (including comparisons between organizations). Furthermore, in-depth interviews are planned for both purposes: to get additional qualitative information that will enrich the model and will be part of the verification process. Finally, a focus group 
interview will be planned with international experts: practitioners from industries and other researchers.

Furthermore, during the study, a correlation between aspects of operational activities and top drawbacks/benefits of telework was observed. In addition, it is very important to note that the correlation coefficients are fully based on responses by the sample group and are hence strictly specific to this study.

The most important result of this study is the $3 \mathrm{~S}$ generalized framework for the manufacturing industry. The framework might look arbitrary, but it is important to acknowledge the fact that the manufacturing industry is very vast. In addition, the framework can be tailored to the size of operations of a specific organization. As the name suggests, the framework is three-fold and is generalized for the whole manufacturing industry. In the current predicament, the survive phase is vital for every business, as it emphasizes keeping the business afloat and avoiding bankruptcy while ensuring the health safety of all the stakeholders during this pandemic. Additional practical results of this research proposition and evaluation of improvement actions could be applied by manufacturing companies and be helpful for survival during pandemic time. Such improvement actions could become a basis of best practices implemented in future by industry.

Author Contributions: Conceptualization: B.G. and M.A.D.; methodology: B.G. and M.A.D.; software: M.A.D.; validation: A.B. and B.G.; formal analysis: B.G. and M.A.D.; investigation: M.A.D. and B.G.; resources: M.A.D.; data curation: M.A.D.; writing—original draft preparation: M.A.D., B.G. and A.B.; writing - review and editing: A.B. and B.G.; visualization: B.G. and M.A.D.; supervision: B.G.; project administration: B.G.; funding acquisition: A.B. All authors have read and agreed to the published version of the manuscript.

Funding: The APC was funded by the Council of Scientific Discipline Management and Quality Sciences of the Warsaw University of Technology.

Institutional Review Board Statement: Not applicable.

Informed Consent Statement: Not applicable.

Data Availability Statement: Data could be obtained upon request from authors.

Acknowledgments: We would also like to thank the Kaushik Cesan team, in particular, Ritesh Vankar, for the incredible support during the whole development of the research as well as for providing the data necessary for the achievement of this work.

Conflicts of Interest: The authors declare no conflict of interest.

\section{Appendix A. A Survey for Line Workers: Impact of COVID_19 on Operational Activities of Kaushik Cesan Pvt. Ltd.}

This survey is to evaluate what changed after the onset of corona virus at Kaushik Cesan Pvt. Ltd.

https:/ / tinyurl.com/Survey-A-Line-Workers (accessed on 18 December 2020).

\section{Appendix A.1. Metrics}

1. Name and Surname

2. Designation (Position)

\section{Appendix A.2. General Facts on Work during Pandemic}

3. Did you feel comfortable (safe) working on factory floor? Single choice. Yes/No/Other (explain:

4. Were you given some new safety training during this period of time? Single choice. Yes/No/Other (explain:

5. Was there an increase in number of shifts per day? Single choice. 
Yes/No/Other (explain:

6. Was there an increase in duration of shift? Single choice.

Yes/No/Other (explain:

7. Did you work on weekends? Single choice.

Yes/No/Other (explain:

8. Were lunch breaks split into different groups? Single choice.

Yes/No/Other (explain:

Appendix A.3. Impacts Related to Manufacturing and Supply Chains

Please indicate to what extent do you agree with above statement $(0: 0 \% ; 1: 20 \%$; 2: 40\%; 3: 60\%; 4: 80\%; 5: 100\%) (approx.).

9. To what extent was there impact on operational activities?

Least $\quad 0 \quad 1 \quad 2 \quad 3 \quad 4 \quad 5 \quad 5$ Highest

10. To what extent was there shortage of raw materials to carry out operational activities?

Least $\quad 0 \quad 1 \quad 2 \quad 3 \quad 3 \quad 4 \quad 5$ Highest

11. To what extent was there unavailability of transport to carry out operational activities?

Least $\quad 0 \quad 1 \quad 2 \quad 3 \quad 3 \quad 4 \quad 5$ Highest

12. To what extent was there unavailability of workforce to carry out operational activities?

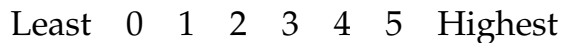

13. To what extent was there shortage in demand (orders)?

Least $\quad 0 \quad 1 \quad 2 \quad 3 \quad 3 \quad 4 \quad 5$ Highest

14. To what extent was there insufficient production to fulfill demand?

Least $\quad 0 \quad 1 \quad 2 \quad 3 \quad 3 \quad 4 \quad 5$ Highest

15. To what extent was there overproduction at any point of time?

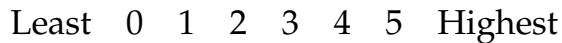

16. To what extent was there an increase in equipment and machine failures?

Least $\quad 0 \quad 1 \quad 2 \quad 3 \quad 3 \quad 4 \quad 5$ Highest

17. To what extent was there an increase in workload during this period of time?

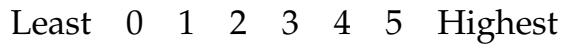

18. To what extent was there a decline in working hours per month?

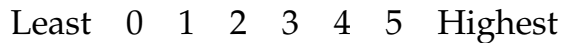

19. To what extent did restriction placed by local law enforcement impact operations?

Least $\quad 0 \quad 1 \quad 2 \quad 3 \quad 3 \quad 4 \quad 5$ Highest

Appendix A.4. Work from Home Implications at Kaushik Cesan. How Was Work from Home Different from Working in the Office?

20. Did you work from home at any point of time in this pandemic? Single choice. Yes/No/Other (explain:

21. Top Benefits of Remote work. Multiple choice.

- Flexible schedule

- Working from any location

- No commute 
- More time spent with family

- Other:

22. Top Struggles of Remote work. Multiple choice.

- Collaboration and/or communication

- Loneliness

- $\quad \mathrm{TV}$ and/or media streaming distractions

- Less mental stimuli

- Spouse and/or partner

- Kids

- Pets

- Roommate(s)

- Staying motivated

- Reliable Internet connection

- Lack of necessary equipment

- Longer breaks

- Other:

23. How was work from home different from working in office? e.g., "There was not efficient collaboration with workers, which increased unplanned downtime", etc.

24. In future, would you prefer working from home or working from the office? e.g., "There was not efficient collaboration with workers, which increased unplanned downtime", etc. Single choice.

Work from home/work from office/other (explain:

\section{Appendix B. A Survey for Managers: Changes after the Onset of Corona Virus at Kaushik Cesan Pvt. Ltd.}

https:/ / tinyurl.com/Survey-B-Manager (accessed on 18 December 2020).

This survey is to evaluate what changed after the onset of corona virus at Kaushik Cesan Pvt. Ltd. Questions 1-24 are the same as in Appendix A. A survey for line workers.

Work from Home Implications at Kaushik Cesan. How Was Work from Home Different from Working in the Office? Continued from Question 24 in Appendix A

25. What were top concerns of managers for employees working from home? Multiple choice.

- $\quad$ Reduced team's cohesiveness

- Reduced employees' focus

- Reduced employees' productivity

- Maintaining company's culture

- Employees' overworking

- Employees' career implications

- Other:

26. Was there a hiring freeze at any point of time during the COVID-19 pandemic? Single choice.

Yes/No/Other (explain:

27. Were research and development projects paused during this period? Single choice. Yes/No/Other (explain:

28. To what extent are operations at Kaushik Cesan automated? Please indicate to what extent do you agree with above statement $(0: 0 \% ; 1: 20 \% ; 2: 40 \% ; 3: 60 \% ; 4: 80 \%$; 5: 100\%) (approx.). 


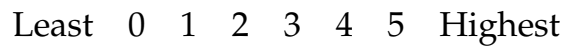

29. To what extent does Kaushik Cesan use advanced technologies like big data analysis? Please indicate to what extent do you agree with above statement $(0: 0 \% ; 1: 20 \%$; 2: 40\%; 3: 60\%; 4: 80\%; 5: 100\%) (approx.).

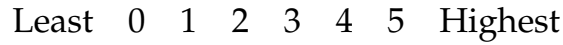

30. To what extent is Kaushik Cesan equipped with the necessary software used for sales forecasting, planning, logistics, and so on? Please indicate to what extent do you agree with the above statement (0: $0 \% ; 1: 20 \% ; 2: 40 \% ; 3: 60 \% ; 4: 80 \%$; 5: 100\%) (approx.).

Least $\quad 0 \quad 1 \quad 2 \quad 2 \quad 3 \quad 4 \quad 5$ Highest

31. To what extent is Kaushik Cesan investing in risk analysis to mitigating such risks? Please indicate to what extent do you agree with above statement (0: $0 \% ; 1: 20 \%$; 2: 40\%; 3: 60\%; 4: 80\%; 5: 100\%) (approx.).

Least $\quad 0 \quad 1 \quad 2 \quad 2 \quad 3 \quad 4 \quad 5$ Highest

32. Did you individually and the company have some contingency plan for disruption of this magnitude?

\section{Appendix C. Spearman's Ranks for Correlations between Various Aspects of Operational Activities, Top Benefits, and Top Struggles of Remote Work}

Table A1. Spearman's ranks for correlations between various aspects of operational activities.

\begin{tabular}{|c|c|c|c|c|c|c|c|c|c|c|c|c|}
\hline \multicolumn{2}{|c|}{ Spearman's Rho Correlation } & GI & $\mathbf{R M}$ & UT & UW & SO & IP & OP & MF & IW & DW & RL \\
\hline \multirow{2}{*}{ GI } & Correlation Coefficient & - & & & & & & & & & & \\
\hline & Sig. (2-tail.) & & & & & & & & & & & \\
\hline \multirow{2}{*}{$\mathbf{R M}$} & Correlation Coefficient & -0.142 & - & & & & & & & & & \\
\hline & Sig. (2-tail.) & 0.358 & & & & & & & & & & \\
\hline \multirow{2}{*}{ UT } & Correlation Coefficient & -0.031 & 0.314 & - & & & & & & & & \\
\hline & Sig. (2-tail.) & 0.840 & 0.038 & & & & & & & & & \\
\hline \multirow{2}{*}{ UW } & Correlation Coefficient & 0.010 & -0.102 & -0.032 & - & & & & & & & \\
\hline & Sig. (2-tail.) & 0.950 & 0.511 & 0.836 & & & & & & & & \\
\hline \multirow{2}{*}{ SO } & Correlation Coefficient & 0.047 & 0.195 & 0.204 & -0.168 & - & & & & & & \\
\hline & Sig. (2-tail.) & 0.761 & 0.204 & 0.185 & 0.275 & & & & & & & \\
\hline \multirow{2}{*}{ IP } & Correlation Coefficient & -0.265 & -0.209 & 0.127 & -0.218 & -0.209 & - & & & & & \\
\hline & Sig. (2-tail.) & 0.083 & 0.173 & 0.412 & 0.156 & 0.173 & & & & & & \\
\hline \multirow{2}{*}{ OP } & Correlation Coefficient & 0.167 & 0.376 & 0.044 & 0.023 & 0.373 & -0.384 & - & & & & \\
\hline & Sig. (2-tail.) & 0.278 & 0.012 & 0.774 & 0.882 & 0.013 & 0.010 & & & & & \\
\hline \multirow{2}{*}{ MF } & Correlation Coefficient & 0.313 & -0.326 & -0.328 & 0.384 & -0.059 & -0.040 & 0.051 & - & & & \\
\hline & Sig. (2-tail.) & 0.039 & 0.031 & 0.030 & 0.010 & 0.704 & 0.796 & 0.741 & & & & \\
\hline \multirow{2}{*}{ IW } & Correlation Coefficient & -0.164 & -0.162 & -0.287 & 0.231 & -0.454 & -0.106 & -0.441 & 0.084 & - & & \\
\hline & Sig. (2-tail.) & 0.287 & 0.294 & 0.059 & 0.132 & 0.002 & 0.494 & 0.003 & 0.587 & & & \\
\hline \multirow{2}{*}{ DW } & Correlation Coefficient & -0.085 & -0.018 & -0.129 & -0.209 & 0.109 & -0.067 & 0.068 & 0.051 & -0.222 & - & \\
\hline & Sig. (2-tail.) & 0.585 & 0.907 & 0.404 & 0.173 & 0.480 & 0.666 & 0.662 & 0.744 & 0.147 & & \\
\hline \multirow{2}{*}{ RL } & Correlation Coefficient & 0.227 & -0.088 & -0.070 & 0.113 & -0.166 & -0.253 & -0.108 & 0.205 & 0.082 & 0.200 & - \\
\hline & Sig. (2-tail.) & 0.138 & 0.572 & 0.653 & 0.467 & 0.281 & 0.098 & 0.485 & 0.183 & 0.595 & 0.194 & \\
\hline
\end{tabular}


Legend:

- $\quad \mathrm{RM}$ (shortage of raw materials)

- UT (unavailability of transport)

- UW (unavailability of workforce)

- SO (shortage of demand/orders)

- IP (insufficient production capacity)

- OP (overproduction)

- $\quad$ MF (machine failures)

- IW (increase in workload)

- DW (decline in working hours)

- $\quad$ RL (restriction of law)

Table A2. Spearman's ranks for correlations between top struggles of remote work (TSRW) and aspects of operational activities.

\begin{tabular}{|c|c|c|c|c|c|c|c|c|c|c|c|c|}
\hline & & RL & UT & GI & $\mathbf{R M}$ & UW & SO & IW & DW & MF & OP & IP \\
\hline \multirow{2}{*}{ TSRW1 } & orrelation $\mathrm{Co}$ & .386 & 0.383 & .152 & 0.083 & -0.201 & 0.383 & 0.315 & 0.216 & -0.193 & 0.044 & 0.365 \\
\hline & Sig. (2-tail) & 0.010 & 0.010 & 0.325 & 0.594 & 0.191 & 0.010 & 0.037 & 0.160 & 0.209 & 0.775 & 0.015 \\
\hline \multirow{2}{*}{ TSRW2 } & orrelation Coef & 0.201 & -0.182 & 0.050 & -0.357 & -0.266 & 0.111 & 0.090 & -0.081 & -0.067 & -0.035 & 0.150 \\
\hline & Sig. (2-tail.) & 0.191 & 0.236 & 0.746 & 0.017 & 0.081 & 0.474 & 0.563 & 0.602 & 0.666 & 0.820 & 0.330 \\
\hline \multirow{2}{*}{ TSRW3 } & Correlation Coefficient & -0.393 & 0.071 & -0.187 & 0.045 & -0.351 & 0.274 & 0.004 & 0.074 & -0.120 & -0.093 & 0.323 \\
\hline & Sig. (2-tail.) & 0.008 & 0.646 & 0.225 & 0.773 & 0.020 & 0.072 & 0.981 & 0.633 & 0.437 & 0.547 & 0.033 \\
\hline \multirow{2}{*}{ TSRW4 } & Correlation Coefficient & -0.459 & 0.151 & -0.217 & -0.072 & -0.200 & 0.272 & -0.108 & -0.002 & -0.104 & 0.170 & 0.314 \\
\hline & Sig. (2-ta & 0.002 & 0.326 & 0.157 & 0.644 & 0.192 & 0.074 & 0.484 & 0.990 & 0.502 & 0.269 & 0.038 \\
\hline \multirow{2}{*}{ TSRW5 } & Correlation Coeffic & -0.165 & 0.228 & 0.068 & 0.093 & -0.142 & 0.213 & -0.430 & 0.307 & -0.081 & 0.093 & 0.166 \\
\hline & Sig. $(2-t$ & 0.284 & 0.136 & 0.663 & 0.548 & 0.357 & 0.164 & 0.004 & 0.043 & 0.603 & 0.549 & 0.282 \\
\hline \multirow{2}{*}{ TSRW6 } & Correlation Coefficient & -0.024 & 0.259 & 0.206 & 0.077 & -0.083 & 0.324 & -0.425 & 0.227 & -0.072 & 0.237 & -0.071 \\
\hline & Sig. (2-tail.) & 0.876 & 0.090 & 0.179 & 0.620 & 0.594 & 0.032 & 0.004 & 0.139 & 0.641 & 0.122 & 0.647 \\
\hline \multirow{2}{*}{ TSRW7 } & Correla & -0.162 & 0.248 & -0.041 & 0.028 & 0.020 & 0.089 & -0.204 & 0.037 & -0.094 & 0.033 & 0.010 \\
\hline & Sig. (2-tail.) & 0.293 & 0.104 & 0.794 & 0.857 & 0.900 & 0.564 & 0.185 & 0.810 & 0.542 & 0.831 & 0.951 \\
\hline \multirow{2}{*}{ TSRW8 } & Correlation Coefficient & 0.000 & 0.000 & 0.000 & 0.000 & 0.000 & 0.000 & 0.000 & 0.000 & 0.000 & 0.000 & 0.000 \\
\hline & Sig. (2-tail.) & 0.000 & 0.000 & 0.000 & 0.000 & 0.000 & 0.000 & 0.000 & 0.000 & 0.000 & 0.000 & 0.000 \\
\hline \multirow{2}{*}{ TSRW9 } & Correlation Coefficient & -0.284 & -0.046 & -0.287 & -0.093 & -0.142 & 0.279 & 0.089 & -0.062 & -0.052 & -0.138 & 0.355 \\
\hline & Sig. (2-tail.) & 0.062 & 0.767 & 0.059 & 0.548 & 0.357 & 0.066 & 0.568 & 0.689 & 0.735 & 0.371 & 0.018 \\
\hline \multirow{2}{*}{ TSRW10 } & Correlation Coefficient & 0.110 & -0.084 & -0.067 & 0.037 & 0.019 & 0.020 & 0.000 & 0.055 & -0.115 & 0.236 & -0.094 \\
\hline & tail.) & 0.479 & 0.586 & 0.668 & 0.813 & 0.902 & 0.900 & 10.000 & 0.723 & 0.457 & 0.122 & 0.542 \\
\hline \multirow{2}{*}{ TSRW11 } & Correlation Coefficient & -0.098 & 0.031 & -0.217 & 0.113 & -0.350 & 0.189 & 0.050 & 0.223 & -0.156 & -0.114 & 0.396 \\
\hline & Sig. (2-tail.) & 0.527 & 0.839 & 0.157 & 0.464 & 0.020 & 0.219 & 0.746 & 0.145 & 0.313 & 0.463 & 0.008 \\
\hline \multirow{2}{*}{ TSRW12 } & Correlation Coefficient & -0.239 & 0.006 & -0.186 & -0.153 & -0.069 & 0.433 & -0.055 & 0.066 & -0.047 & 0.016 & 0.170 \\
\hline & Sig. (2-tail.) & 0.119 & 0.970 & 0.227 & 0.321 & 0.656 & 0.003 & 0.724 & 0.670 & 0.763 & 0.919 & 0.270 \\
\hline
\end{tabular}

TSRW (top struggles of remote work):

- TSRW1 (collaboration and communication)

- TSRW2 (loneliness)

- $\quad$ TSRW3 (TV and/or media streaming)

- $\quad$ TSRW4 (less mental stimuli)

- TSRW5 (spouse and/or partner)

- TSRW6 (kids) 
- $\quad$ TSRW7 (pets)

- TSRW8 (roommate(s))

- $\quad$ TSWR9 (staying motivated)

- TSRW10 (reliable internet connection)

- $\quad$ TSRW11 (lack of necessary equipment(s))

- $\quad$ TSRW12 (longer breaks)

Table A3. Spearman's ranks for correlations between top benefits of remote work (TBRW) and aspects of operational activities.

\begin{tabular}{ccccccccc}
\hline & \multicolumn{2}{c}{ TBRW1 } & \multicolumn{2}{c}{ TBRW2 } & \multicolumn{2}{c}{ TBRW3 } & \multicolumn{2}{c}{ TBRW4 } \\
\hline & $\begin{array}{c}\text { Correlation } \\
\text { Coefficient }\end{array}$ & Sig. (2-tail.) & $\begin{array}{c}\text { Correlation } \\
\text { Coefficient }\end{array}$ & Sig. (2-tail.) & $\begin{array}{c}\text { Correlation } \\
\text { Coefficient }\end{array}$ & Sig. (2-tail.) & $\begin{array}{c}\text { Correlation } \\
\text { Coefficient }\end{array}$ & Sig. (2-tail.) \\
\hline RL & -0.451 & 0.002 & -0.340 & 0.024 & -0.298 & 0.050 & -0.390 & 0.009 \\
\hline UT & 0.391 & 0.009 & 0.260 & 0.088 & 0.265 & 0.083 & 0.388 & 0.009 \\
\hline GI & -0.181 & 0.239 & -0.139 & 0.369 & -0.116 & 0.454 & -0.139 & 0.369 \\
\hline RM & 0.173 & 0.261 & -0.057 & 0.712 & 0.002 & 0.990 & 0.357 & 0.018 \\
\hline UW & -0.291 & 0.055 & -0.120 & 0.437 & -0.124 & 0.422 & -0.200 & 0.192 \\
\hline SO & 0.452 & 0.002 & 0.354 & 0.018 & 0.500 & 0.001 & 0.472 & 0.001 \\
\hline IW & -0.321 & 0.033 & -0.283 & 0.063 & -0.284 & 0.062 & -0.407 & 0.006 \\
\hline DW & 0.171 & 0.266 & 0.136 & 0.378 & 0.051 & 0.742 & 0.136 \\
\hline MF & -0.286 & 0.060 & -0.053 & 0.731 & -0.063 & 0.684 & -0.281 & 0.378 \\
\hline OP & 0.155 & 0.314 & -0.006 & 0.967 & 0.108 & 0.484 & 0.296 \\
\hline IP & 0.310 & 0.041 & 0.431 & 0.004 & 0.242 & 0.113 & 0.114 & 0.051 \\
\hline
\end{tabular}

Legend: see Table A1.

TBRW (top benefits of remote work):

- $\quad$ TBRW1 (flexible schedule)

- TBRW2 (working from any location),

- TBRW3 (no commute)

- $\quad$ TBRW4 (more time spent with family)

Appendix D. Assessment of Proposed Improvements Actions

Table A4. Environmental assessment identification matrix.

\begin{tabular}{|c|c|c|c|c|c|}
\hline \multirow{2}{*}{ Improvement Activity } & \multicolumn{3}{|c|}{ Environmental Attributes } \\
\cline { 2 - 5 } & Air & Noise & Water & $\begin{array}{c}\text { Oand/Soil } \\
\text { Health }\end{array}$ \\
\hline Supply chain reorganization & $\mathrm{X}$ & $\mathrm{X}$ & $\mathrm{X}$ & $\mathrm{X}$ \\
\hline Industry 4.0 initiatives & $\mathrm{X}$ & $\mathrm{X}$ & $\mathrm{X}$ & $\mathrm{X}$ \\
\hline Ensure workers safety & & & $\mathrm{X}$ & $\mathrm{X}$ \\
\hline $\begin{array}{c}\text { Accommodating workers in vicinity of } \\
\text { factory premises }\end{array}$ & $\mathrm{X}$ & $\mathrm{X}$ & $\mathrm{X}$ & $\mathrm{X}$ \\
\hline Reorganize production space & $\mathrm{X}$ & $\mathrm{X}$ & $\mathrm{X}$ & $\mathrm{X}$ \\
\hline Engage workers & & & & $\mathrm{X}$ \\
\hline Improve worker skills & & & & \\
\hline Increase storage capacity & $\mathrm{X}$ & & $\mathrm{X}$ & \\
\hline Contract with multiple regional suppliers & & $\mathrm{X}$ & $\mathrm{X}$ & $\mathrm{X}$ \\
\hline Preventive maintenance & $\mathrm{X}$ & $\mathrm{X}$ & $\mathrm{X}$ & $\mathrm{X}$ & \\
\hline Automate production & $\mathrm{X}$ & $\mathrm{X}$ & $\mathrm{X}$ & $\mathrm{X}$ \\
\hline
\end{tabular}


Table A4. Cont.

\begin{tabular}{|c|c|c|c|c|c|}
\hline \multirow{2}{*}{ Improvement Activity } & \multicolumn{4}{c|}{ Environmental Attributes } \\
\cline { 2 - 5 } & Air & Noise & Water & $\begin{array}{c}\text { Occupational } \\
\text { Health }\end{array}$ & \\
\hline $\begin{array}{c}\text { Equip employees with improved } \\
\text { software and their training }\end{array}$ & & & & \\
\hline Improve morale of employees & & & & $X$ \\
\hline $\begin{array}{c}\text { Provide proper equipment's to } \\
\text { employees working from home }\end{array}$ & & & & \\
\hline Ensure collaboration & & & & \\
\hline Explaining goals and priorities & & & & $X$ \\
\hline Standardize operations & $X$ & $X$ & & $X$ \\
\hline
\end{tabular}

Table A5. Environmental assessment for proposed improvement actions.

\begin{tabular}{|c|c|c|c|c|}
\hline \multirow{2}{*}{$\begin{array}{l}\text { Environmental } \\
\text { Attributes }\end{array}$} & \multirow{2}{*}{ Cause } & \multicolumn{3}{|c|}{ Impact Characteristics } \\
\hline & & Nature & Duration & Reversibility \\
\hline \multicolumn{5}{|c|}{ 1. Reorganization of supply chain } \\
\hline Air & \multirow{2}{*}{$\begin{array}{l}\text { Transportation of materials and } \\
\text { goods locally on shorter distances }\end{array}$} & Positive & Long term & Reversible \\
\hline Noise & & Positive & Long term & Reversible \\
\hline Land/soil & $\begin{array}{l}\text { Spillage of materials during } \\
\text { transportation }\end{array}$ & Positive & Long term & Reversible \\
\hline \multicolumn{5}{|c|}{ 2. Industry 4.0 initiatives } \\
\hline Air & \multirow{5}{*}{$\begin{array}{l}\text { Less ecological footprint, less } \\
\text { waste and scrap, efficient } \\
\text { collaboration between machines } \\
\text { and humans, more job openings }\end{array}$} & Positive & Long term & Reversible \\
\hline Noise & & Positive & Long term & Reversible \\
\hline Water & & Positive & Long term & Reversible \\
\hline Land/soil & & Positive & Long term & Reversible \\
\hline Occupational health & & Positive & Long term & Reversible \\
\hline \multicolumn{5}{|c|}{ 3. Ensure workers safety } \\
\hline Occupational health & Safer working conditions & Positive & Long term & Reversible \\
\hline \multicolumn{5}{|c|}{ 4. Accommodating workers in vicinity of factory premises } \\
\hline Air & \multirow{4}{*}{$\begin{array}{l}\text { Impact due to human activity is } \\
\text { slightly negative, but less } \\
\text { commute is very positive, also the } \\
\text { safety of workers during these } \\
\text { uncertain times is vital. }\end{array}$} & Positive & Long term & Reversible \\
\hline Noise & & Positive & Long term & Reversible \\
\hline Water & & Positive & Long term & Reversible \\
\hline Land/soil & & Positive & Long term & Reversible \\
\hline \multicolumn{5}{|c|}{ 5. Reorganization of production space } \\
\hline Air & \multirow{4}{*}{$\begin{array}{l}\text { Shifting machines and tools across } \\
\text { factory floor, more space needed, } \\
\text { and chance of leakage of } \\
\text { lubricants, oil spillage }\end{array}$} & Negative & Long term & Reversible \\
\hline Noise & & Negative & Long term & Reversible \\
\hline Water & & Negative & Long term & Reversible \\
\hline Land/soil & & Negative & Long term & Reversible \\
\hline Occupational health & Safer working conditions & Positive & Long term & Reversible \\
\hline \multicolumn{5}{|c|}{ 6. Engage workers } \\
\hline Occupational health & Motivated employees & Positive & Long term & Reversible \\
\hline \multicolumn{5}{|c|}{ 7. Improve worker skills } \\
\hline Occupational health & Satisfied employees & Positive & Long term & Irreversible \\
\hline
\end{tabular}


Table A5. Cont.

\begin{tabular}{|c|c|c|c|c|}
\hline \multirow{2}{*}{$\begin{array}{l}\text { Environmental } \\
\text { Attributes }\end{array}$} & \multirow{2}{*}{ Cause } & \multicolumn{3}{|c|}{ Impact Characteristics } \\
\hline & & Nature & Duration & Reversibility \\
\hline \multicolumn{5}{|c|}{ 8. Increase storage capacity } \\
\hline Air & \multirow{3}{*}{$\begin{array}{l}\text { Handling more products, chance } \\
\text { of spilling liquid materials stores }\end{array}$} & Negative & Long term & Reversible \\
\hline Water & & Negative & Long term & Reversible \\
\hline Land/soil & & Negative & Long term & Reversible \\
\hline \multicolumn{5}{|c|}{ 9. Contract with multiple regional suppliers } \\
\hline Occupational health & $\begin{array}{l}\text { Continuous supply of materials } \\
\text { means continuous production, and } \\
\text { job security amid this time }\end{array}$ & Positive & Long term & Reversible \\
\hline \multicolumn{5}{|c|}{ 10. Preventive maintenance } \\
\hline Air & \multirow{4}{*}{$\begin{array}{l}\text { More probability of scrap, } \\
\text { lubricants spillage, and so on, but } \\
\text { lesser probability of unexpected } \\
\text { breakdowns, accidents, etc. }\end{array}$} & Positive & Long term & Reversible \\
\hline Noise & & Positive & Long term & Reversible \\
\hline Water & & Positive & Long term & Reversible \\
\hline Land/soil & & Positive & Long term & Reversible \\
\hline \multicolumn{5}{|c|}{ 11. Automated production } \\
\hline Air & \multirow{5}{*}{$\begin{array}{l}\text { Autonomous machine operations } \\
\text { and lesser effort needed for shop } \\
\text { workers leads to greater daily } \\
\text { consumptions of media, increase } \\
\text { noise, etc., but decreased number } \\
\text { of unexpected breakdowns and } \\
\text { accidents, which could lead to } \\
\text { spillage, injuries, etc. }\end{array}$} & Positive & Long term & Reversible \\
\hline Noise & & Positive & Long term & Reversible \\
\hline Water & & Positive & Long term & Reversible \\
\hline Land/soil & & Positive & Long term & Reversible \\
\hline Occupational health & & Positive & Long term & Reversible \\
\hline \multicolumn{5}{|c|}{ 12. Equip employees with improved software's and their training } \\
\hline Occupational health & Satisfaction of employees & Positive & Long term & Irreversible \\
\hline \multicolumn{5}{|c|}{ 13. Improve morale of employees } \\
\hline Occupational health & Motivated employees & Positive & Long term & Irreversible \\
\hline \multicolumn{5}{|c|}{ 14. Provide proper equipment's to employees working from home. } \\
\hline Occupational health & Easy accomplishment of tasks & Positive & Long term & Reversible \\
\hline \multicolumn{5}{|c|}{ 15. Ensure collaboration } \\
\hline Occupational health & $\begin{array}{c}\text { Satisfaction of employees and } \\
\text { improved communication }\end{array}$ & Positive & Long term & Reversible \\
\hline \multicolumn{5}{|c|}{ 16. Explaining goals and priorities } \\
\hline Occupational health & $\begin{array}{l}\text { Focused employees and } \\
\text { convenient work }\end{array}$ & Positive & Long term & Irreversible \\
\hline \multicolumn{5}{|c|}{ 17. Standardize operations } \\
\hline Air & \multirow{3}{*}{$\begin{array}{l}\text { Emission due to operations, with } \\
\text { improved productivity and } \\
\text { consistent quality }\end{array}$} & Neutral & Long term & Reversible \\
\hline Noise & & Neutral & Long term & Reversible \\
\hline Water & & Neutral & Long term & Reversible \\
\hline Occupational health & Reduced work stress & Positive & Long term & Irreversible \\
\hline
\end{tabular}


Table A6. Social assessment of improvement actions.

\begin{tabular}{|c|c|c|c|c|c|c|c|}
\hline \multirow[b]{2}{*}{ Improvement Activity } & \multicolumn{7}{|c|}{ Social Impacts } \\
\hline & 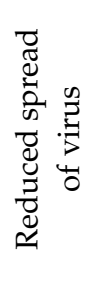 & 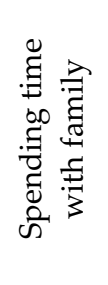 & 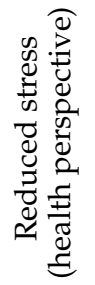 & 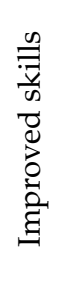 & 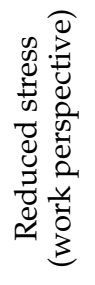 & 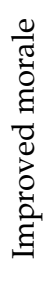 & 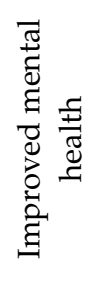 \\
\hline Supply chain reorganization & & & & & $x$ & & $x$ \\
\hline Industry 4.0 initiatives & $X$ & $X$ & $X$ & $x$ & $X$ & & \\
\hline Ensure workers safety & $x$ & $x$ & $X$ & & & $x$ & $x$ \\
\hline $\begin{array}{l}\text { Accommodating workers in vicinity of } \\
\text { factory premises }\end{array}$ & $X$ & & $X$ & & $X$ & & $X$ \\
\hline Reorganize production space & $x$ & & $x$ & & & $x$ & $x$ \\
\hline Engage workers & & & & $x$ & & $X$ & $x$ \\
\hline Improve worker skills & & & & $x$ & $x$ & $X$ & $x$ \\
\hline Increase storage capacity & & & & & $x$ & $x$ & $x$ \\
\hline $\begin{array}{l}\text { Contract with multiple regional } \\
\text { suppliers }\end{array}$ & & & & & $\mathrm{X}$ & $x$ & $X$ \\
\hline Preventive maintenance & & & & & $X$ & $x$ & \\
\hline Automate production & $x$ & $x$ & $x$ & $x$ & $x$ & & \\
\hline $\begin{array}{l}\text { Equip employees with improved } \\
\text { software and their training }\end{array}$ & & & & $x$ & $\mathrm{X}$ & $x$ & $\mathrm{X}$ \\
\hline Improve morale of employees & & & & & & $X$ & $x$ \\
\hline $\begin{array}{l}\text { Provide proper equipment to } \\
\text { employees working from home }\end{array}$ & $X$ & $X$ & $X$ & & $X$ & $x$ & $x$ \\
\hline Ensure collaboration & $x$ & $x$ & $x$ & & $x$ & $x$ & $x$ \\
\hline Explaining goals and priorities & & & & & $X$ & $x$ & $X$ \\
\hline Standardize operations & & & & $x$ & $X$ & $X$ & $X$ \\
\hline
\end{tabular}

Table A7. Sustainability assessment of proposed improvement actions.

\begin{tabular}{|c|c|c|c|c|c|c|c|c|c|c|c|c|c|c|c|c|c|}
\hline \multirow[b]{2}{*}{$\begin{array}{l}\text { Improvement } \\
\text { Activity }\end{array}$} & \multicolumn{17}{|c|}{ Sustainable Development Goals (SDGs) } \\
\hline & $\begin{array}{l}\overbrace{0} \\
0 \\
0 \\
0 \\
0 \\
z\end{array}$ & 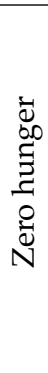 & 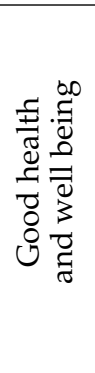 & 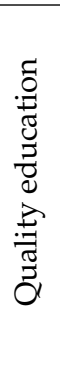 & 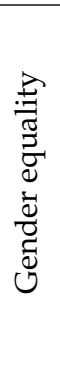 & 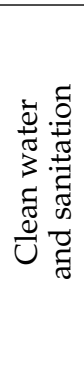 & 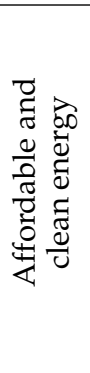 & 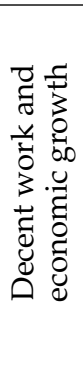 & 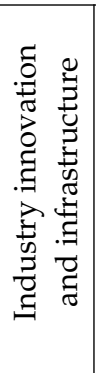 & 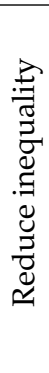 & 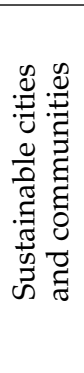 & 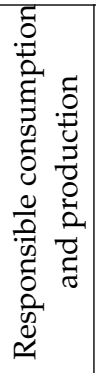 & 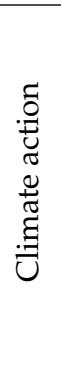 & 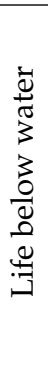 & 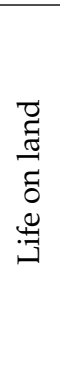 & 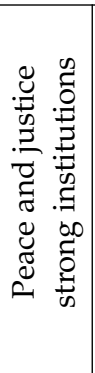 & 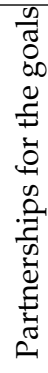 \\
\hline $\begin{array}{l}\text { Supply chain } \\
\text { reorganization }\end{array}$ & $X$ & $X$ & & & & & & $X$ & $X$ & $x$ & $X$ & $X$ & & & & & $X$ \\
\hline $\begin{array}{c}\text { Industry } 4.0 \\
\text { initiatives }\end{array}$ & $X$ & $x$ & $x$ & & & & & $X$ & $x$ & & $X$ & $X$ & $x$ & & & & \\
\hline $\begin{array}{c}\text { Ensure workers } \\
\text { safety }\end{array}$ & $X$ & $x$ & $X$ & & & & & $X$ & $X$ & & $X$ & & & & $X$ & $X$ & $X$ \\
\hline $\begin{array}{l}\text { Accommodating } \\
\text { workers in } \\
\text { vicinity of } \\
\text { factory premises }\end{array}$ & $x$ & $X$ & $X$ & & & $X$ & & $X$ & $X$ & $X$ & $X$ & $X$ & & & $X$ & $X$ & $X$ \\
\hline
\end{tabular}


Table A7. Cont.

\begin{tabular}{|c|c|c|c|c|c|c|c|c|c|c|c|c|c|c|c|c|c|}
\hline \multirow[b]{2}{*}{$\begin{array}{c}\text { Improvement } \\
\text { Activity }\end{array}$} & \multicolumn{17}{|c|}{ Sustainable Development Goals (SDGs) } \\
\hline & $\begin{array}{l}3 \\
\sum_{0}^{2} \\
0 \\
0 \\
0 \\
0 \\
2\end{array}$ & 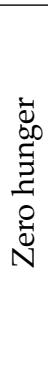 & 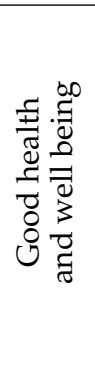 & 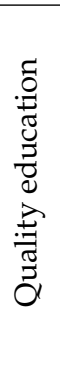 & 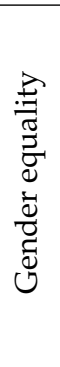 & 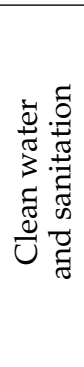 & 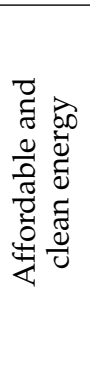 & 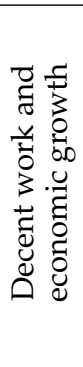 & 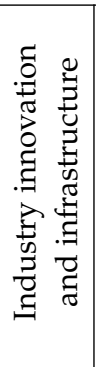 & 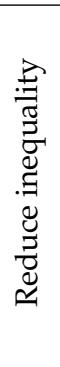 & 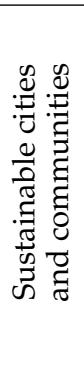 & 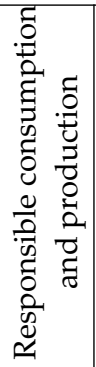 & 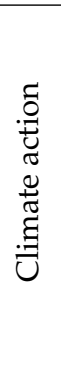 & 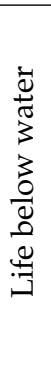 & 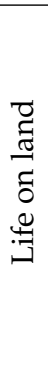 & 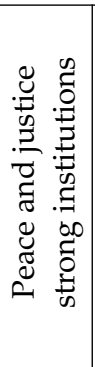 & 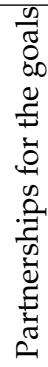 \\
\hline $\begin{array}{c}\text { Reorganize } \\
\text { production space }\end{array}$ & & & $X$ & & & & & & $X$ & & $\mathrm{X}$ & & & & & & \\
\hline Engage workers & & & $X$ & $X$ & & & & $X$ & $X$ & $X$ & $X$ & $X$ & & & & $\mathrm{X}$ & $X$ \\
\hline $\begin{array}{l}\text { Improve worker } \\
\text { skills }\end{array}$ & & & $X$ & $X$ & & & & $X$ & $x$ & $x$ & & $\mathrm{X}$ & & & & $\mathrm{X}$ & \\
\hline $\begin{array}{c}\text { Increase storage } \\
\text { capacity }\end{array}$ & & & & & & & & $X$ & $X$ & & & $X$ & & & & & \\
\hline $\begin{array}{l}\text { Contract with } \\
\text { multiple regional } \\
\text { suppliers. }\end{array}$ & $\mathrm{X}$ & $X$ & $X$ & & & & & $X$ & & $X$ & $x$ & $\mathrm{X}$ & & & & $x$ & $x$ \\
\hline $\begin{array}{l}\text { Preventive } \\
\text { maintenance }\end{array}$ & & & & & & & & & $X$ & & $\mathrm{X}$ & $X$ & & & & & \\
\hline $\begin{array}{c}\text { Automate } \\
\text { production }\end{array}$ & $\mathrm{X}$ & $\mathrm{X}$ & $X$ & & & & & $X$ & $X$ & & $\mathrm{X}$ & $X$ & $\mathrm{X}$ & & & & \\
\hline $\begin{array}{l}\text { Equip employees } \\
\text { with improved } \\
\text { software and } \\
\text { their training }\end{array}$ & & & $X$ & $X$ & & & & $X$ & $X$ & & & $X$ & & & & $X$ & \\
\hline $\begin{array}{c}\text { Improve morale } \\
\text { of employees }\end{array}$ & & & $X$ & & & & & $X$ & & $x$ & $X$ & $X$ & & & $x$ & $X$ & $X$ \\
\hline $\begin{array}{l}\text { Provide proper } \\
\text { equipment to } \\
\text { employees } \\
\text { working from } \\
\text { home }\end{array}$ & & & $X$ & $X$ & & & & $X$ & $X$ & & & $X$ & & & & $X$ & \\
\hline $\begin{array}{c}\text { Ensure } \\
\text { collaboration }\end{array}$ & & & & & & & & $X$ & & & $X$ & $X$ & & & & & $x$ \\
\hline $\begin{array}{l}\text { Explaining goals } \\
\text { and priorities }\end{array}$ & & & $X$ & $X$ & & & & $X$ & $X$ & $x$ & $X$ & $X$ & & & & $x$ & $X$ \\
\hline $\begin{array}{l}\text { Standardize } \\
\text { operations }\end{array}$ & $X$ & $X$ & $X$ & $X$ & & & $X$ & $X$ & $X$ & & & $X$ & $X$ & & $X$ & & $X$ \\
\hline
\end{tabular}

Table A8. Economic impacts of proposed improvement.

\begin{tabular}{|c|c|c|c|}
\hline Improvement Activity & Costs & Benefits \\
\hline Supply chain reorganization & $\begin{array}{c}\text { Compromise on quality and variety in } \\
\text { raw materials, costs related to } \\
\text { changing to new suppliers. }\end{array}$ & $\begin{array}{c}\text { Lower transportations costs, shorter } \\
\text { lead times, increased supply chain } \\
\text { flexibility. }\end{array}$ & $\begin{array}{c}\text { Improved productivity, improved } \\
\text { collaboration of machines with } \\
\text { employees, reduced risk of } \\
\text { disruptions (like COVID-19), } \\
\text { sustainable operations. }\end{array}$ \\
\hline Industry 4.0 initiatives & $\begin{array}{c}\text { Investment costs related new } \\
\text { technologies/machines and their } \\
\text { training }\end{array}$ & $\begin{array}{c}\text { Availability of workforce to carry out } \\
\text { operations, loyalty and trust of } \\
\text { workers }\end{array}$ \\
\hline Ensure workers safety & $\begin{array}{c}\text { Costs of sanitization, temperature } \\
\text { checks, safety training. }\end{array}$ & costs $<$ benefits \\
\hline
\end{tabular}


Table A8. Cont.

\begin{tabular}{|c|c|c|c|}
\hline $\begin{array}{l}\text { Accommodating workers in vicinity } \\
\text { of factory premises }\end{array}$ & $\begin{array}{l}\text { Costs of arranging workers } \\
\text { accommodation }\end{array}$ & $\begin{array}{l}\text { No transportation organized by a } \\
\text { company, continuity of business } \\
\text { activity. }\end{array}$ & costs $<$ benefits \\
\hline Reorganise production space & $\begin{array}{l}\text { Cost of reorganization of workplace } \\
\text { according to governmental } \\
\text { regulations. } \\
\end{array}$ & Worker's safety & costs $<$ benefits \\
\hline Engage workers & None & $\begin{array}{c}\text { Improved worker morale, improved } \\
\text { productivity, detecting irregularities } \\
\text { quickly }\end{array}$ & costs $<$ benefits \\
\hline Improve worker skills & Training costs & $\begin{array}{l}\text { Skilled workers, cross trained workers } \\
\text { (who can fill for absent colleagues) }\end{array}$ & costs $<$ benefits \\
\hline Increase storage capacity & Cost of renting/constructing storage & $\begin{array}{l}\text { Continuous supply of raw materials } \\
\text { and continuous manufacturing }\end{array}$ & costs $<$ benefits \\
\hline $\begin{array}{l}\text { Contract with multiple regional } \\
\text { suppliers }\end{array}$ & Costs of more complex planning & $\begin{array}{l}\text { Less stoppages due to shortage of } \\
\text { materials }\end{array}$ & costs $<$ benefits \\
\hline Preventive maintenance & Maintenance costs & $\begin{array}{l}\text { Reduced machine/equipment failures, } \\
\text { reduced unplanned downtime, } \\
\text { increases machine life, increased } \\
\text { safety at workplace }\end{array}$ & costs $<$ benefits \\
\hline Automate production & $\begin{array}{l}\text { Automated machining and its training } \\
\text { costs, monitoring systems costs }\end{array}$ & $\begin{array}{l}\text { Reduced need of workers hence labor } \\
\text { costs, high quality and diligent } \\
\text { production, increased safety at } \\
\text { workplace, reduced production costs }\end{array}$ & costs $<$ benefits \\
\hline $\begin{array}{l}\text { Equip employees with improved } \\
\text { software's and their training }\end{array}$ & $\begin{array}{c}\text { Cost of software licenses and their } \\
\text { trainings }\end{array}$ & $\begin{array}{c}\text { Improved customer projections, } \\
\text { improved logistics systems, efficient } \\
\text { production planning }\end{array}$ & costs $<$ benefits \\
\hline Improve morale of employees & None & $\begin{array}{l}\text { Improved worker morale, improved } \\
\text { productivity }\end{array}$ & costs $<$ benefits \\
\hline $\begin{array}{l}\text { Provide proper equipment's to } \\
\text { employees working from home }\end{array}$ & $\begin{array}{c}\text { Costs associated with hardware } \\
\text { equipment }\end{array}$ & $\begin{array}{l}\text { Improved productivity, convenience } \\
\text { in carrying out job responsibilities }\end{array}$ & costs $<$ benefits \\
\hline Ensure collaboration & $\begin{array}{l}\text { Costs associated with viable } \\
\text { communication channel }\end{array}$ & $\begin{array}{l}\text { Efficient communication channel } \\
\text { amongst employees, reduced machine } \\
\text { failures, handling irregular } \\
\text { functioning of machines quickly with } \\
\text { minimal or no downtime. }\end{array}$ & costs $<$ benefits \\
\hline Explaining goals and priorities & None & $\begin{array}{l}\text { Increased productivity, improved } \\
\text { quality of production system, reduced } \\
\text { machine failures, improved morale } \\
\text { and focus of employees. }\end{array}$ & costs $<$ benefits \\
\hline Standardise operations & None & $\begin{array}{l}\text { Reduced downtime, consistent quality, } \\
\text { optimum production. }\end{array}$ & costs $<$ benefits \\
\hline
\end{tabular}

\section{References}

1. Ma, J. China's First Confirmed COVID-19 Case Traced Back to November 17. Available online: https:/ /www.scmp.com/news / china/society / article/3074991/coronavirus-chinas-first-confirmed-covid-19-case-traced-back (accessed on 10 September 2020).

2. WHO. WHO Director-General's Opening Remarks at the Media Briefing on COVID-19-11 March 2020. Available online: https:/ / www.who.int/director-general/speeches/detail/who-director-general-s-opening-remarks-at-the-media-briefing-oncovid-19---11-march-2020 (accessed on 18 December 2020).

3. WHO. India: WHO Coronavirus Disease (COVID-19) Dashboard. Available online: https://covid19.who.int (accessed on 18 December 2020).

4. Wu, S.L.; Mertens, A.N.; Crider, Y.S.; Nguyen, A.; Pokpongkiat, N.N.; Djajadi, S.; Seth, A.; Hsiang, M.S.; Colford, J.M.; Reingold, A.; et al. Substantial Underestimation of SARS-CoV-2 Infection in the United States. Nat. Commun. 2020, 11, 4507. [CrossRef]

5. TNN. India's Covid Cases World's 2nd Highest I India News-Times of India. Available online: https://timesofindia.indiatimes. com/india/indias-covid-cases-worlds-2nd-highest/articleshow/77956328.cms (accessed on 18 December 2020).

6. Seshadri, M.S.; John, T.J. Underestimation of the COVID-19 Burden. Econ. Political Wkly. 2015, 55, 7-8.

7. The National Ministry of Statistics and Programme of India. Estimates of Gross Domestic Product for the Second Quarter (April-June) of 2020-21. Available online: pib.gov.in/Pressreleaseshare.aspx?PRID=1650021 (accessed on 18 December 2020).

8. The National Ministry of Statistics and Programme of India. Estimates of Gross Domestic Product for the Second Quarter (JulySeptember) of 2020-21. Available online: pib.gov.in/Pressreleaseshare.aspx?PRID=1676486 (accessed on 18 December 2020).

9. Ghosh, S.; Das, A.; Hembram, T.K.; Saha, S.; Pradhan, B.; Alamri, A.M. Impact of COVID-19 Induced Lockdown on Environmental Quality in Four Indian Megacities Using Landsat 8 OLI and TIRS-Derived Data and Mamdani Fuzzy Logic Modelling Approach. Sustainability 2020, 12, 5464. [CrossRef]

10. Aruga, K.; Islam, M.M.; Jannat, A. Effects of COVID-19 on Indian Energy Consumption. Sustainability 2020, 12, 5616. [CrossRef]

11. Toscano, D.; Murena, F. The Effect on Air Quality of Lockdown Directives to Prevent the Spread of SARS-CoV-2 Pandemic in Campania Region-Italy: Indications for a Sustainable Development. Sustainability 2020, 12, 5558. [CrossRef]

12. Sahoo, S.; Rani, S.; Parveen, S.; Pal Singh, A.; Mehra, A.; Chakrabarti, S.; Grover, S.; Tandup, C. Self-Harm and COVID-19 Pandemic: An Emerging Concern-A Report of 2 Cases from India. Asian J. Psychiatr. 2020, 51, 102104. [CrossRef] [PubMed] 
13. UNIDO. India's Manufacturing Reels from the Impact of COVID-19| UNIDO. Available online: https://www.unido.org/stories/ indias-manufacturing-reels-impact-covid-19 (accessed on 21 December 2020).

14. Liu, F.; Wang, M.; Zheng, M. Effects of COVID-19 Lockdown on Global Air Quality and Health. Sci. Total Environ. 2021, 755, 142533. [CrossRef] [PubMed]

15. Zhu, G.; Chou, M.C.; Tsai, C.W. Lessons Learned from the COVID-19 Pandemic Exposing the Shortcomings of Current Supply Chain Operations: A Long-Term Prescriptive Offering. Sustainability 2020, 12, 5858. [CrossRef]

16. Guan, D.; Wang, D.; Hallegatte, S.; Davis, S.J.; Huo, J.; Li, S.; Bai, Y.; Lei, T.; Xue, Q.; Coffman, D.; et al. Global Supply-Chain Effects of COVID-19 Control Measures. Nat. Hum. Behav. 2020, 4, 577-587. [CrossRef]

17. Nayyar, D. Lives, Livelihoods and the Economy: India in Pandemic Times. Ind. J. Lab. Econ. 2020, 63, 53-59. [CrossRef] [PubMed]

18. Arora, R.; Arora, P.K.; Kumar, H.; Pant, M. Additive Manufacturing Enabled Supply Chain in Combating COVID-19. J. Ind. Intg. Mgmt. 2020, 5, 495-505. [CrossRef]

19. Nigro, F.; Tavares, M.; Sato de Souza de Bustamante Monteiro, M.; Toma, H.K.; Faria de Freitas, Z.M.; de Abreu Garófalo, D.; Geraldes Bordalo MontáAlverne, M.A.; Barros dos Passos, M.M.; Pereira dos Santos, E.; Ricci-Júnior, E. Changes in Workflow to a University Pharmacy to Facilitate Compounding and Distribution of Antiseptics for Use against COVID-19. Res. Soc. Adm. Pharm. 2021, 17, 1997-2001. [CrossRef]

20. Kuo, S.; Ou, H.-T.; Wang, C.J. Managing Medication Supply Chains: Lessons Learned from Taiwan during the COVID-19 Pandemic and Preparedness Planning for the Future. J. Am. Pharm. Assoc. 2021, 61, e12-e15. [CrossRef] [PubMed]

21. Belhadi, A.; Kamble, S.; Jabbour, C.J.C.; Gunasekaran, A.; Ndubisi, N.O.; Venkatesh, M. Manufacturing and Service Supply Chain Resilience to the COVID-19 Outbreak: Lessons Learned from the Automobile and Airline Industries. Technol. Forecast. Soc. Chang. 2021, 163, 120447. [CrossRef]

22. Mahajan, K.; Tomar, S. COVID-19 and Supply Chain Disruption: Evidence from Food Markets in India. Am. J. Agric. Econ. 2021, 103, 35-52. [CrossRef]

23. Ino, E.; Watanabe, K. The Impact of COVID-19 on the Global Supply Chain: A Discussion on Decentralization of the Supply Chain and Ensuring Interoperability. J. Disaster Res. 2021, 16, 56-60. [CrossRef]

24. Qin, X.; Godil, D.I.; Khan, M.K.; Sarwat, S.; Alam, S.; Janjua, L. Investigating the Effects of COVID-19 and Public Health Expenditure on Global Supply Chain Operations: An Empirical Study. Oper. Manag. Res. 2021, 1-13. [CrossRef]

25. Kunovjanek, M.; Wankmüller, C. An Analysis of the Global Additive Manufacturing Response to the COVID-19 Pandemic. J. Manuf. Technol. Manag. 2020, 32, 75-100. [CrossRef]

26. Javaid, M.; Haleem, A.; Vaishya, R.; Bahl, S.; Suman, R.; Vaish, A. Industry 4.0 Technologies and Their Applications in Fighting COVID-19 Pandemic. Diabetes Metab. Syndr. Clin. Res. Rev. 2020, 14, 419-422. [CrossRef]

27. Javaid, M.; Haleem, A.; Vaish, A.; Vaishya, R.; Iyengar, K.P. Robotics Applications in COVID-19: A Review. J. Ind. Intg. Mgmt. 2020, 05, 441-451. [CrossRef]

28. Cyfert, S.; Glabiszewski, W.; Zastempowski, M. Impact of Management Tools Supporting Industry 4.0 on the Importance of CSR during COVID-19. Generation Z. Energies 2021, 14, 1642. [CrossRef]

29. Kamarthi, S.; Li, W. Technology Enablers for Manufacturing Resilience in the COVID-19 and Post-COVID-19 Era. Smart Sustain. Manuf. Syst. 2020, 4, 294-298. [CrossRef]

30. Hauser, P.; Schönheit, D.; Scharf, H.; Anke, C.-P.; Möst, D. Covid-19's Impact on European Power Sectors: An Econometric Analysis. Energies 2021, 14, 1639. [CrossRef]

31. Aday, S.; Aday, M.S. Impact of COVID-19 on the Food Supply Chain. Food Qual. Saf. 2020, 4, 167-180. [CrossRef]

32. Coughlin, T. Impact of COVID-19 on the Consumer Electronics Market. IEEE Consum. Electron. Mag. 2021, 10, 58-59. [CrossRef]

33. Stojčić, N. Učinci pandemije COVID-19 na izvoznu konkurentnost poduzeća prerađivačke industrije u Hrvatskoj. Ekon. Misao Praksa 2020, 29, 347-366. [CrossRef]

34. Barcaccia, G.; D'Agostino, V.; Zotti, A.; Cozzi, B. Impact of the SARS-CoV-2 on the Italian Agri-Food Sector: An Analysis of the Quarter of Pandemic Lockdown and Clues for a Socio-Economic and Territorial Restart. Sustainability 2020, 12, 5651. [CrossRef]

35. Kaushik Cesan. Kaushik Cesan Asphalt Batch Mix Catalogue. Kaushik. 2020. Available online: www.kaushikengineeringworks. com (accessed on 18 January 2021).

36. Lavrakas, P. Encyclopedia of Survey Research Methods; Sage Publications, Inc.: Thousand Oaks, CA, USA, 2008. ISBN 978-1-4129-1808-4.

37. Cai, M.; Luo, J. Influence of COVID-19 on Manufacturing Industry and Corresponding Countermeasures from Supply Chain Perspective. J. Shanghai Jiaotong Univ. 2020, 25, 409-416. [CrossRef]

38. cricket.com.au LIVE REPORT: Impact of COVID 19 on Manufacturing. Available online: https: / / www.youtube.com/watch?v= oCOfMjbz-ro\&t=2264s (accessed on 18 January 2021).

39. Shaw, J.; Day, T.; Malik, N.; Barber, N.; Wickenheiser, H.; Fisman, D.N.; Bogoch, I.; Brownstein, J.I.; Williamson, T. Working in a Bubble: How Can Businesses Reopen While Limiting the Risk of COVID-19 Outbreaks? CMAJ 2020, 192, E1362-E1366. [CrossRef]

40. Big Fish Employer Services. 5 Reasons Cross Training Employees Is Essential, During COVID-19 and Beyond. Available online: https:/ / bigfishemployerservices.com/cross-training-employees-during-covid/ (accessed on 18 January 2021).

41. McKinsey. Industry 4.0: Reimagining Manufacturing Operations after COVID-19. Available online: https://www.mckinsey.com/ business-functions/operations / our-insights/industry-40-reimagining-manufacturing-operations-after-covid-19 (accessed on 18 January 2021).

42. Chary, S.N. Production and Operations Management; McGraw-Hill: New York, NY, USA, 2009; ISBN 978-0-07-009153-5. 
43. UN. UNSDG I Policy Brief: The World of Work and COVID-19. Available online: https://unsdg.un.org/resources/policy-briefworld-work-and-covid-19 (accessed on 28 January 2021).

44. Taqi, H.; Ahmed, H.; Paul, S.; Garshasbi, M.; Ali, S.M.; Kabir, G.; Paul, S. Strategies to Manage the Impacts of the COVID19 Pandemic in the Supply Chain: Implications for Improving Economic and Social Sustainability. Sustainability 2020, 12, 9483. [CrossRef]

45. Rapaccini, M.; Saccani, N.; Kowalkowski, C.; Paiola, M.; Adrodegari, F. Navigating Disruptive Crises through Service-Led Growth: The Impact of COVID-19 on Italian Manufacturing Firms. Ind. Mark. Manag. 2020, 88, 225-237. [CrossRef]

46. Biswas, T.K.; Das, M.C. Selection of the Barriers of Supply Chain Management in Indian Manufacturing Sectors Due to COVID-19 Impacts. Oper. Res. Eng. Sci. Theory Appl. 2020, 3, 1-12. [CrossRef]

47. MIT Center for Transportation \& Logistics. A Coronavirus Briefing-The Impact of COVID-19 on Business and Supply Chain. Available online: https:/ / www.youtube.com/watch?app=desktop\&v=Br0FqIuWAHA\&t=688s (accessed on 25 January 2021).

48. Hudson Institute. How Will the COVID-19 Pandemic Change Manufacturing and Technology Supply Chains? Available online: https:/ / www.youtube.com/watch?app=desktop\&v=FL1-hT061Gk (accessed on 25 January 2021).

49. MachineMetrics. Live Report \#2: The Impact of COVID-19 on Manufacturing in Real-Time. Available online: https://www. youtube.com/watch?app=desktop\&v=KWOqBx71zqE\&t=2069s (accessed on 25 January 2021).

50. MachineMetrics. State of the Industry: The Impact of COVID-19 on Manufacturing, August Update. Available online: https: / / www.youtube.com/watch?v=kHZT2ug80H4 (accessed on 25 January 2021).

51. Victoria State Gov. Industry Restart Guidelines Manufacturing (Excludes Meat and Seafood Processing). Available online: https:/ / www.coronavirus.vic.gov.au/sites/default/files / 2021-01/Industry\%20Restart\%20Guidelines\%20-\%20 Manufacturing\%20COVIDSafe\%20Summer.pdf (accessed on 28 January 2021).

52. UN. The Sustainable Development Goals Report 2020. United Nations. 2020. ISBN 978-92-1-004960-3. Available online: www.un-ilibrary.org (accessed on 18 January 2021). 